1

2

3

\title{
Coiled-coils in the YopD translocator family: a predicted structure unique to the YopD N-terminus contributes to full virulence of Yersinia pseudotuberculosis
}

Tiago R. D. Costa, ${ }^{1,2}$ Ayad A. A. Amer, ${ }^{1,2}$ Maria Fällman, ${ }^{1,2}$ Anna Fahlgren ${ }^{1,2}$ and Matthew S. Francis ${ }^{1,2^{*}}$ Department of Molecular Biology ${ }^{1}$ and Umeå Centre for Microbial Research (UCMR), ${ }^{2}$ Umeå University, SE-901 87 Umeå, Sweden

Running head: Coiled-coil domain required for full YopD function

* Corresponding author: matthew.francis@ molbiol.umu.se.

\begin{abstract}
Abbreviations: T3S(S), type III secretion (system); Yops, Yersinia outer proteins; Ysc, Yersinia secretion; CD, calcium dependent; TS, temperature dependent; BHI, Brain Heart Infusion; LB, LuriaBertani; TMH, Modified Higuchi’s Medium; BLAST, Basic Local Alignment Search Tool; CFU, colony forming unit
\end{abstract}




\section{ABSTRACT}

3 Pathogenic Yersinia all harbor a virulence plasmid-encoded Ysc-Yop T3SS. In this system, translocator

4 function is performed by the hydrophobic proteins YopB and YopD. With the goal to better understand

5 how YopD orchestrates yop-regulatory control, translocon pore formation and Yop effector translocation,

6 we performed an in silico prediction of coiled-coil motifs in YopD and YopD-like sequences from other

7 bacteria. Of interest was a predicted N-terminal coiled-coil that occurred solely in Yersinia YopD

8 sequences. To investigate if this unique feature was biologically relevant, two in cis point mutations were

9 generated with a view to disrupting this putative structure. Both mutants maintained full T3SS function in 10 vitro in terms of environmental control of Yops synthesis and secretion, effector toxin translocation and 11 evasion of phagocytosis and killing by cultured immune cells. However, these same mutants were 12 attenuated for virulence in a murine oral-infection model. The cause of this tardy disease progression is 13 unclear. However, these data indicate that any structural flaw in this element unique to the N-terminus 14 will subtly compromise an aspect of YopD biology. Sub-optimal T3SSs are then formed that are unable to 15 fortify Yersinia against attack by the host innate and adaptive immune response.

17 Keywords: Ysc-Yop, Type III secretion system, YopD, YopB, hydrophobic, translocon pore 


\section{Introduction}

3

4 The coiled-coil is a tertiary motif frequently present in a broad variety of proteins. It consists of a 5 repeated number of amphipathic $\alpha$-helices (usually 2 to 5 ) that interlace around each other creating a 6 super-coiled structure characterized by hydrophobic residue periodicity, called the heptad-repeat (Cohen 7 and Parry, 1990; Lupas et al., 1991). This motif is a popular scaffold for diverse protein-protein 8 interaction interfaces because of its inherent flexibility and heterogeneous architecture (Burkhard et al., 9 2001; Grigoryan and Keating, 2008). Their biological significance is further highlighted by recent in 10 silico-based observations that suggested as much as $5 \%$ of the eukaryote proteome and $10 \%$ of the 11 prokaryotic and archaebacteria proteomes contain predicted coiled-coil motifs (Liu and Rost, 2001; Rose 12 et al., 2005). Interestingly, some of those prokaryotic proteins were predicted to be substrates of the type 13 III secretion system (T3SS), a prominent virulence determinant of many Gram-negative bacteria (Delahay 14 and Frankel, 2002; Pallen et al., 1997). Since many of these T3SS substrates are prone to remodel 15 biological functions inside the eukaryotic cell, it is no surprise that some have incorporated this motif 16 during their evolutionary course as a means to cross-talk with host cell proteins.

17 Like many Gram-negative bacteria, pathogenic Yersinia sp. utilizes a T3SS to translocate virulence 18 factors directly into the interior of immune cells to subvert host innate immunity that promotes 19 extracellular bacterial colonization in lymphoid tissue (Cornelis, 2006; Galan and Wolf-Watz, 2006). 20 These are evolutionarily related to the flagellar biogenesis system and are thought to have evolved by 21 horizontal gene transfer among the Gram-negative proteobacteria (Gophna et al., 2003; Troisfontaines 22 and Cornelis, 2005). The Yersinia system - denoted Ysc-Yop for Yersinia secretion and $\underline{\text { Yersinia }}$ outer 23 protein - is encoded on a large virulence plasmid common among all pathogenic strains (Cornelis et al., 24 1998). While T3SSs are widespread, variations exist among them. In fact, the Ysc-Yop T3SS forms a 25 distinct phylogenetic clade that among others, includes T3SSs encoded by Pseudomonas aeruginosa, 26 Photorhabdus luminescens, pathogenic Aeromonas sp., pathogenic Vibrio sp. and Photobacterium 
1 damselae (Troisfontaines and Cornelis, 2005). It is possible that the Ysc-Yop clade has evolved 2 specifically for bacterial evasion of host phagocytosis so that they can remain as an extracellular 3 pathogen, although no doubt each individual pathogen has adapted their cognate systems for use in 4 different hosts and/or host-specific niches.

5 Although most of the structural components of all T3SSs share similar structural and functional 6 characteristics, the cognate substrates secreted by each individual system display considerable genetic and 7 functional diversity (Erhardt et al., 2010; Tampakaki et al., 2004). Despite this variation, several among 8 them are predicted to incorporate $\alpha$-helical coiled-coil structural elements, indicating that such domains 9 might play important roles in their function (Delahay and Frankel, 2002; Pallen et al., 1997). However, a 10 structure-function analysis has only been experimentally verified in some cases [for example: (Daniell et 11 al., 2001; Delahay et al., 1999; Gazi et al., 2008; Hamad and Nilles, 2007; Knodler et al., 2011; Lawton et 12 al., 2002; Schubot et al., 2005)].

13 The Yersinia secreted translocator YopD is a multifunctional protein that is involved in governing 14 multiple T3SS related activities such as translocon pore assembly in the eukaryotic plasma membrane, 15 effector translocation to the host-cell interior and maintenance of ysc-yop regulatory control in the 16 bacterial cytoplasm. Given this functional repertoire, it is not surprising that YopD possesses distinct 17 functional domains and engages numerous interacting partners (e.g. itself, YopB, YopK, YopE, LcrV, 18 TyeA and SycD/LcrH) (Amer et al., 2011; Costa et al., 2010; Edqvist et al., 2006; Francis et al., 2000; 19 Hartland and Robins-Browne, 1998; Iriarte et al., 1998; Neyt and Cornelis, 1999a; Olsson et al., 2004; 20 Sarker et al., 1998; Thorslund et al., 2011). In several cases, these interactions have been attributed to a C21 terminal amphipathic $\alpha$-helix domain that spans residues 278 to 292 (Costa et al., 2010; Olsson et al., 22 2004; Tengel et al., 2002).

23 As revealed in this and other studies (Bröms et al., 2003; Pallen et al., 1997), a putative C-terminal 24 coiled-coil lies immediately upstream of the amphipathic $\alpha$-helix. We also noted via the COILS 25 webserver (http://pbil.univ-lyon1.fr/) a second putative coiled-coil motif located near to the YopD N26 terminus, although this was with a predictive probability of $<70 \%$ and a small window size $<21$. 
1 Nevertheless, analysis of the numerous YopD-like sequences harbored by other bacterial members of the

2 Ysc-Yop T3SS phylogenic clade consistently failed to predict this putative N-terminal structure. We

3 therefore wondered whether the N-terminal coiled-coil predicted only in YopD of pathogenic Yersinia sp.

4 is important for Ysc-Yop T3SS activity. To address this, we used site directed mutagenesis of residue

$5 \quad \mathrm{Ile}_{32}$ in an attempt to modestly (I32K substitution) or totally (I32P substitution) disrupt the chances of

6 forming this predicted N-terminal coiled-coil. Interestingly, Y. pseudotuberculosis producing $\mathrm{YopD}_{\mathrm{I} 32 \mathrm{~K}}$ or

$7 \mathrm{YopD}_{\mathrm{I} 32 \mathrm{P}}$ maintained a functional T3SS in vitro. Within the in vivo context of a mouse infection model

8 however, the mutants displayed signs of virulence attenuation. These results suggest that this putative $\mathrm{N}-$

9 terminal YopD coiled-coil domain, unique to the Yersinia genus, is required for full function and 10 virulence.

12 2. Materials and methods

2.1. YopD sequence comparisons 23 generated using ClustalW (2.1).

YopD protein sequence from Y. pseudotuberculosis YPIII was retrieved from NCBI sequence database (accession number AAA72322) and used as bait for BLASTP (2.2.26+) analysis against all Yersinia genomes (taxonomy identity: 629) in the NCBI databases. Only matched proteins with minimal Expect (E)-values of 0 were reported. In order to identify YopD-like protein sequence in other bacteria, an unrestricted BLASTP analysis was performed against the entire NCBI genome database. In this case, only significantly matched proteins with minimal E-values of $<$ E-15 were considered. Selected protein 
Bacterial strains and plasmid list used in this study can be found as Table 1. We used $Y$. pseudotuberculosis YPIII/pIB102 (serotype 0:3) as the parental strain which harbors an Ysc-Yop T3SS 3 encoded on the pIB102 virulence plasmid that carries a kanamycin resistance cassette in yadA (Bölin and

4 Wolf-Watz, 1984; Gemski et al., 1980) in addition to a chromosomally-encoded inactive PhoP response 5 regulator (Grabenstein et al., 2004). Unless otherwise stated, Y. pseudotuberculosis and E. coli strains 6 were cultivated at $26^{\circ} \mathrm{C}$ and $37^{\circ} \mathrm{C}$ respectively in Luria-Bertani (LB) broth with aeration. When required, 7 broth was supplemented with kanamycin $(50 \mu \mathrm{g} / \mathrm{ml})$ or chloramphenicol $(25 \mu \mathrm{g} / \mathrm{ml})$. Growth phenotypes 8 produced by the bacterial strains used in this study were achieved by growing the bacterial strains in 9 liquid Modified Higuchi's medium (TMH) supplemented with or without $2.5 \mathrm{mM}$ of $\mathrm{CaCl}_{2}$ at $37^{\circ} \mathrm{C}$ 10 (Straley and Bowmer, 1986). When normal growth occurs in the presence of $2.5 \mathrm{mM}$ of $\mathrm{CaCl}_{2}$ this 11 phenotype was termed calcium dependent (CD). In contrast, when bacteria are unable to grow irrespective 12 of $\mathrm{Ca}^{2+}$ levels, this is termed a temperature sensitive (TS) phenotype (Costa et al., 2010; Francis et al., 13 2001; Olsson et al., 2004).

\subsection{Mutant construction}

Overlap PCR (Higuchi, 1989) was used to generate amplified DNA fragments that incorporate point mutations in yopD and flanked with $\mathrm{XhoI}$ and $\mathrm{XbaI}$ restriction sites using the primer pair combinations listed in Supplementary Table S1. The amplified fragments were first cloned into the pCR®4-TOPO TA 20 cloning vector (Life Technologies Ltd, UK) and sequenced by Eurofins MWG Operon (Ebersberg, 21 Germany). The confirmed fragments were then sub-cloned into the pDM4 suicide vector that contained 22 the $s a c B$ gene encoding for levansucrase, an enzyme toxic to bacteria when grown in the presence of

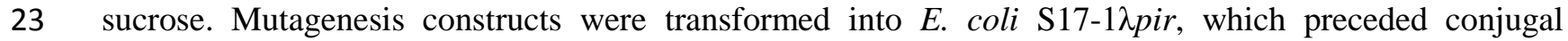
24 mating with $Y$. pseudotuberculosis. Primary allelic exchange events were encouraged by growth on 25 Yersinia selective agar containing kanamycin $(50 \mu \mathrm{g} / \mathrm{ml})$ and chloramphenicol $(25 \mu \mathrm{g} / \mathrm{ml})$. The positive 
1 and 5\% sucrose as detailed previously (Francis and Wolf-Watz, 1998; Milton et al., 1996). All mutants

2 were verified by a diagnostic PCR that amplified DNA flanking both up and down-stream of the mutation

3 and by subsequent sequencing of this amplified product.

$5 \quad$ 2.4. Limited chymotrypsin digestion

6

7 Chymotrypsin digestion was essential performed according to established protocol (Olsson et al., 2004).

8 In short, 0.1 volumes of overnight culture grown in LB broth depleted of $\mathrm{Ca}^{2+}$ ions was subcultured into

$910 \mathrm{ml}$ of the same fresh media and grown for $1 \mathrm{~h}$ at $26^{\circ} \mathrm{C}$ before being shifted to $37^{\circ} \mathrm{C}$ for $3 \mathrm{~h}$. Bacterial10 free supernatants were recovered by a $15 \mathrm{~min}$ centrifugation at $2500 \mathrm{xg}$ and passage through a $0.45 \mu \mathrm{m}$ 11 filter. To all samples, $\mathrm{CaCl}_{2}$ was added to a final concentration of $20 \mathrm{mM}$ followed by incubation at $0^{\circ} \mathrm{C}$ 12 for 20min. Each sample was divided into two 5ml-portions; to one of the vials chymotrypsin was added to 13 a final concentration of $10 \mu \mathrm{g} / \mathrm{ml}$. The duplicate sample remained untreated to control for spontaneous 14 proteolysis. Following incubation for $30 \mathrm{~min}$ at $0^{\circ} \mathrm{C}$, proteinase activity was quenched by the addition of 150.1 volume of $100 \%(\mathrm{v} / \mathrm{v})$ trichloroacetic acid and incubation at $0^{\circ} \mathrm{C}$ for $1 \mathrm{~h}$. Protein was pelleted by 16 centrifugation for $10 \mathrm{~min}$ at $2500 \mathrm{xg}$ and each precipitate dissolved in $50 \mu \mathrm{l}$ of loading buffer (50mM Tris$17 \mathrm{HCl}, \mathrm{pH} 6.8,2 \%$ SDS, $10 \%$ glycerol, $5 \% \beta$-mercaptoethanol, $0.1 \%$ bromophenol blue). Samples were 18 fractionated in an $18 \%$ acrylamide SDS-PAGE gel and cleaved YopD peptides identified by immunoblot 19 on polyvinyl difluoride (PVDF) membrane with rabbit anti-YopD polyclonal antisera.

21 2.5. Chemical cross-linking

23 Chemical cross-linking of YopD was adapted from our previous study (Costa et al., 2010). Briefly, 0.1 24 volume of overnight culture grown in $\mathrm{BHI}$ broth depleted of $\mathrm{Ca}^{2+}$ ions was sub-cultured in $2 \mathrm{ml}$ of the 25 same fresh media and grown for $1 \mathrm{~h}$ at $26^{\circ} \mathrm{C}$ followed by $3 \mathrm{~h}$ at $37^{\circ} \mathrm{C}$. Cell density of the individual 
1 cultures were standardize by spectrophoretic measurement at an optical density of $600 \mathrm{~nm}$. Bacterial free

2 supernatants were recovered by centrifugation and the EGS cross-linker added to a final concentration of

$30.5 \mathrm{mM}$. Following incubation for $2 \mathrm{~h}$ at $0^{\circ} \mathrm{C}$, the cross-linking reaction was terminated during $15 \mathrm{~min}$

4 incubation at ambient temperature by the addition of Tris- $\mathrm{HCl}(\mathrm{pH} 7.5)$ buffer to a final concentration of

5 50mM. Samples were then prepared for fractionation on a $12 \%$ acrylamide SDS-PAGE gel by the

6 addition of 4x loading buffer (200mM Tris-HCl, pH 6.8, 8\% SDS, 40\% glycerol, $20 \% \beta$-mercaptoethanol,

$7 \quad 0.4 \%$ bromophenol blue) into $150 \mathrm{ul}$ of sample reaction. The oligomeric state of YopD was identified by

8 immunoblot on PVDF membrane with rabbit anti-YopD polyclonal antisera.

9

10 2.6. Protein stability

12 Resistance of the generated YopD derivatives to endogenous proteases was tested following growth of 13 the bacteria in BHI (Brain Heart Infusion) broth supplemented with $2.5 \mathrm{mM}$ of $\mathrm{CaCl}_{2}(\mathrm{Feldman}$ et al., 14 2002). Protein fractions collected at various time points subsequent to blocking de novo protein synthesis 15 by the addition of $50 \mu \mathrm{g} / \mathrm{ml}$ chloramphenicol were analyzed by SDS-PAGE and transferred onto a 16 nitrocellulose membrane using a semi-dry transfer system. The immobilized YopD was identified using a 17 rabbit polyclonal YopD antiserum. An anti-rabbit antibody conjugated with horseradish peroxidase (GE 18 healthcare) and a homemade luminol detection solution was used for Western blot detection.

20 2.7. In vitro analysis of protein synthesis and secretion

Assessment of synthesis and secreted of T3S substrates was preformed according to established

24 Olsson et al., 2004). Briefly, overnight cultures were back diluted 10 times and the production of T3S 25 substrates was induced by a temperature shift from $26^{\circ} \mathrm{C}$ to $37^{\circ} \mathrm{C}$ for $3 \mathrm{~h}$ in $\mathrm{BHI}$ broth depleted of $\mathrm{Ca}^{2+}$. 
1 Bacterial cultures were divided into pellets (synthesis) and supernatant (secretion) fractions and separated

2 by SDS-PAGE followed by immunoblotting. Specific T3S substrates were indentified with rabbit

3 polyclonal antiserum raised against YopD, YopB, YopE and LcrV. After treatment with horseradish

4 perixidase conjugated anti-rabbit antibody the detection was completed with homemade luminol detection 5 solution.

6

$7 \quad$ 2.8. Contact-dependent erythrocyte lysis and carbohydrate osmoprotection

8

9 For the hemolysis assay using horse blood, overnight bacterial cultures were grown in LB broth depleted 10 of $\mathrm{Ca}^{2+}$ ions and supplemented with $75 \mathrm{mM}$ of $\mathrm{NaCl}$. Into fresh $2 \mathrm{ml}$ medium, 0.1 volumes were 11 subcultured and then incubated for $1 \mathrm{~h}$ at $26^{\circ} \mathrm{C}$. A further $1 \mathrm{ml}$ of $42^{\circ} \mathrm{C}$ prewarmed medium was added 12 before incubating at $37^{\circ} \mathrm{C}$ for $1 \mathrm{~h}$. The horse blood was prepared by washing three times with fresh LB 13 broth and was then resuspended in half of the volume in LB preheated to $37^{\circ} \mathrm{C}$. Bacteria cultures were 14 standardized to the same optical density by spectrophoretic measurement at $600 \mathrm{~nm}$. The bacteria were 15 then harvested by centrifugation and the pellet thoroughly resuspended in $1 \mathrm{ml}$ of blood (equivalent to $2 \mathrm{x}$ $1610^{11}$ erythrocytes). Samples were centrifuged at $3500 \mathrm{rpm}$ for $5 \mathrm{~min}$ and then incubated for $1 \mathrm{~h}$. To measure 17 hemoglobin release, samples were mixed and $100 \mu \mathrm{l}$ aliquots transferred to wells of a microtiter plate 18 containing an equal volume of PBS prior to optical density measurement at 545nm. For the 19 osmoprotection assay using the carbohydrates raffinose, dextrin 15 and dextran 4, we followed the 20 method of Holmström and collegues (Holmström et al., 1997).

22 2.9. Hela cells infection assay

24 For cultivation and infection of human HeLa epithelial cell line for the cytotoxicity assay, we followed 25 well-established protocols (Francis and Wolf-Watz, 1998; Rosqvist et al., 1991). The ability of Yersinia 
1 expressing various yopD derivatives to intoxicate eukaryotic cells with the YopE cytotoxin was accessed

2 by HeLa cell monolayer cytotoxicity assay. The cell morphology change from oblong to round was

3 followed by light microscopy for a period of $2 \mathrm{~h}$. The change induced by parental Yersinia (YPIII/pIB102)

4 defines the upper limit while an oblong morphology maintained by the $\Delta y o p D$ mutant (YPIII/pIB621)

5 defines the lower limit.

6 For the proteinase $\mathrm{K}$ digestion and digitonin solubility assay, $10 \mathrm{~cm}$ diameter tissue culture petri dishes 7 were seeded with $2 \times 10^{6} \mathrm{HeLa}$ cells in Eagle Minimal Essential Medium (MEM) with Earle's salts (MP

8 Biomedicals) supplemented with $10 \%$ FCS, 1\% PeSt, L-glutamine and sodium pyruvate and grown

9 overnight in $5 \% \mathrm{CO}_{2}$ at $37^{\circ} \mathrm{C}$. Overnight bacterial cultures were grown at $26^{\circ} \mathrm{C}$ in $2 \mathrm{ml}$ of LB broth with 10 appropriate antibiotic selection. The next day, 0.01 volumes of these were sub-cultured into $12 \mathrm{ml}$ of 11 MEM without antibiotic and grown for $30 \mathrm{~min}$ at $26^{\circ} \mathrm{C}$ followed by $1 \mathrm{~h}$ at $37^{\circ} \mathrm{C}$. Prior to infection, Hela 12 cell monolayers were washed twice with PBS and then overlaid with 5ml MEM without antibiotic. 13 Twenty minutes pre-infection, a final concentration of $0.5 \mu \mathrm{g} / \mathrm{ml}$ of cytochalasin $\mathrm{D}$ was added and 14 maintained throughout to block bacterial uptake. The cell-free media was then carefully aspirated and 15 monolayers infected in a volume of $5 \mathrm{ml}$ in duplicate with a multiplicity of infection (MOI) of $\sim 10$. 16 Infections were allowed to proceed for $3 \mathrm{~h}$ in $5 \% \mathrm{CO}_{2}$ at $37^{\circ} \mathrm{C}$, after which time non-adherent bacteria

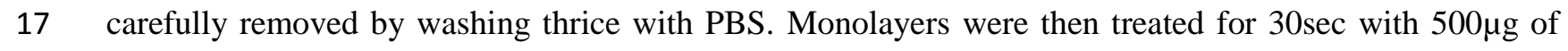
18 proteinase $\mathrm{K}$ solubilized in $1 \mathrm{ml}$ of PBS. Following removal of the proteinase $\mathrm{K}$ solution, monolayers were 19 further incubated at ambient temperature for 20min. proteinase $\mathrm{K}$ activity was then blocked by the 20 addition of $500 \mu \mathrm{l}$ of freshly prepared $4 \mathrm{mM}$ phenylmethylsulfonyl fluoride (in PBS). To one of the 21 duplicate monolayers, $400 \mu 1$ of $1 \%$ digitonin in PBS was added, while $400 \mu 1$ PBS was added to the other.

22 Material was harvested in collection tubes and incubated for $20 \mathrm{~min}$ at ambient temperature. Soluble 23 fractions were clarified by centrifugation and the supernatants subsequently analyzed by Western blot. 24 Translocated YopE and YopH effectors were identified with specific rabbit anti-YopE and goat anti- 
1 YopH antisera. Samples were also probed with mouse anti-ERK1 antibody (BD Pharmingen) specific for

2 the C-terminal region of ERK1 to confirm the loading of an equal quantity of protein in each lane.

$4 \quad 2.10$. Resistance to phagocytic uptake and killing

5

6 For measurements of bacterial uptake and killing by murine J774A.1 macrophage-like cell monolayers

7 (ATCC, Virginia, USA) we used the method of Bartra and colleagues (Bartra et al., 2001). Into individual

8 wells of a 24-well tissue culture plate, $1 \times 10^{5}$ J774A.1 macrophages-like cells were seeded with

9 Dulbecco's Modified Eagle Medium (DMEM) High Glucose, GlutaMAX ${ }^{\mathrm{TM}}$ (Life Technologies Ltd, 10 Paisley, UK) supplemented with $10 \%$ FCS and $1 \%$ PeSt and then grown for $24 \mathrm{~h}$ in $5 \% \mathrm{CO}_{2}$ at $37^{\circ} \mathrm{C}$. 11 Additionally, bacterial cultures were grown with aeration overnight at $26^{\circ} \mathrm{C}$ in $\mathrm{BHI}$ broth minus $\mathrm{Ca}^{2+}$ ions. 12 Next day, $20 \mu 1$ of overnight culture was transferred into $3 \mathrm{ml}$ of antibiotic free DMEM and incubated at $1326^{\circ} \mathrm{C}$ for $30 \mathrm{~min}$ prior to a shift to $37^{\circ} \mathrm{C}$ for $60 \mathrm{~min}$. In preparation for infection with a MOI of $\sim 1, \mathrm{~J} 774 \mathrm{~A} .1$ 14 monolayers were washed twice with $1 \mathrm{ml}$ PBS and then each monolayer overlaid with $1 \mathrm{ml}$ antibiotic free 15 DMEM. Bacterial infections were then initiated and synchronized with centrifugation at 1500rpm for $165 \mathrm{~min}$. After $30 \mathrm{~min}$ incubation in $5 \% \mathrm{CO}_{2}$ at $37^{\circ} \mathrm{C}$, supernatants were carefully aspirated and monolayers 17 then gently overlaid with $250 \mu 1$ of antibiotic free DMEM medium and incubated further. At time intervals $182 \mathrm{~h}$ and $6 \mathrm{~h}, 250 \mu \mathrm{l} 1 \%(\mathrm{v} / \mathrm{v})$ Triton $\mathrm{X}-100$ was added, mixed and then incubated for $10 \mathrm{~min}$ at ambient 19 temperature. Serial dilutions of cell lysate were performed in PBS to obtain colony forming units. These 20 values are expressed as means \pm standard errors (SEM) of the results of six independent experiments. The 21 non-parametric two-tailed Mann-Whitney $U$-test performed using GraphPad Prism version 5.00 for 22 Windows, GraphPad Software, San Diego California USA, www.graphpad.com was used to analyze the 23 differences in data sets. Differences with a probability value of $P<0.05$ were considered significant. 24

\section{2.11. Murine infection model}


Female eight-week-old BALB/c mice (Taconic, Denmark) were given food and water ad libitum. For 3 infection, groups of six mice were deprived of food and water $16 \mathrm{~h}$ prior to oral infection. For infection,

4 bacteria grown overnight in $\mathrm{LB}$ broth at $26^{\circ} \mathrm{C}$ were pelleted and serially diluted to $10^{9}, 10^{8}$ and $10^{7}$

5 CFUs/ml in sterile tap water supplemented with $150 \mathrm{mM} \mathrm{NaCl}$. Cultures were serially diluted and plated

6 to establish viable bacterial cell counts for verification of the infection dose. Mice were individually

7 monitored for 14 days post infection for weight, ruffled fur, diarrhea, crumpled back, and listlessness. The

$8 \mathrm{ID}_{50}$ (50\% infectious dose) was determined using the Reed-Muench method (Reed and Muench, 1938).

9 Infected mice showing symptoms of a terminal infection were immediately euthanized. The experiments 10 were conducted in accordance with the guidelines of the Animal Ethics Committee of Umeå University 11 (permit number A90-11).

\section{3. Results}

14

15 3.1. Heterogeneity of YopD sequences

16

17 It was apparent from the first report of YopD primary sequence that it represented a novel class of 18 protein (Håkansson et al., 1993). Using this original YopD protein sequence with accession number 19 AAA72322 as a consensus - designated YPIII_YopD after the source strain Y. pseudoduberculosis YPIII 20 serotype 0:3 - we first performed a BLASTP analysis against all other Yersinia sequences available in the 21 NCBI database. This comprised of $>60$ entries and corresponded to $>50 Y$. pestis, 2 Y. pseudotuberculosis 22 and $>8 Y$. enterocolitica isolates (Table 2). This approach revealed 5 different homology groups of YopD 23 sequences, designated A to E (Fig. 1 and Table 2). Consistent with the close evolutionary relationship 24 between $Y$. pseudotuberculosis and Y. pestis (Achtman et al., 1999; Skurnik et al., 2000; Wren, 2003), 25 group A sequences exhibited a single amino acid change (G283S) across the entire 306 residues, and are 26 derived entirely from other $Y$. pseudotuberculosis and $Y$. pestis isolates. Moreover, we observed a greater 
1 heterogeneity with YopD sequences derived from $Y$. enterocolitica, which is a reflection of the much

2 earlier divergence of this species from Y. pseudotuberculosis (Achtman et al., 1999). Y. enterocolitica 3 group B sequences boast six genetic alterations (K27G, I32V, T113S, E172D, G183S and I185A), group 4 C has seven (Q17R, K27G, I32V, T113S, E172D, G183S and I185A), group D with eight (L18I, K27G, 5 I32V, T111A, E172D, G183S, I185T and G186S) and group E with nine (L18I, K27G, I32V, T111A, 6 E172D, M179L, G183S, I185T and G186S). Based on these comparisons, the G183S substitution is 7 recognized as common to all other YopD sequences, whereas the additional K27G, I32V and E172D 8 divergences are also common to all $Y$. enterocolitica isolates (Fig. 1).

9 Outside of the Yersinia genus, YopD-like proteins exist in the genera Aeromonas, Photorhabdus and 10 Vibrio as well as Pseudomonas aeruginosa and Photobacterium damselae (Table 2). Of these, AopD 11 from A. veronii exhibits $49.3 \%$ amino acid identity to YPIII_YopD over much of the protein length. This 12 reduces to a modest $27.8 \%$ identity for the open reading frame annotated as VDA_000190 from $P b$. 13 damselae. Only twenty one residues are identical among all YopD-like sequences (Fig. 1). However, 14 these gather in two groups; one located in a segment bordering the internal YopD putative membrane 15 spanning domain and the other in a C-terminal segment overlapping with a putative coiled-coil. These 16 two discrete foci correspond to domains that in YopD of pathogenic Yersinia are critical for Ysc-Yop 17 T3SS function (Olsson et al., 2004) (Costa et al., unpublished data). We therefore posit that these are core 18 functional domains of all YopD-like proteins.

\subsection{A predicted coiled-coil structure unique to the YopD sequences of Yersinia sp.}

25 proteins (Liu and Rost, 2001; Rose et al., 2005). Corroborating earlier reports (Bröms et al., 2003; Pallen 26 et al., 1997), a coiled-coil domain in the C-terminus was predicted with high probability in YopD 
1 sequences derived from Yersinia (Supplementary Fig. S1 and Table 2). Significantly, mutational analysis

2 of this region in YPIII_YopD indicates a critical role in T3SS function and virulence (Olsson et al., 2004)

3 (Costa et al., unpublished data). A similarly predicted C-terminal coiled-coil segment was also observed

4 in many of the YopD-like sequences sourced from other bacterial genera, reinforcing the idea that this

5 represents a core functional domain. The two exceptions to this were LopD from Photorhabdus sp. and

6 PopD from P. aeruginosa (Supplementary Fig. S1 and Table 2). Hence, unique features can evolve

7 among individual YopD-like homologues that is presumably necessary to support function within their 8 cognate T3SS (Bröms et al., 2003).

9 Albeit with much lower probability, in silico analysis predicted a second modestly sized coiled-coil 10 structure to lie at the N-terminus of YopD sequences from Yersinia (Supplementary Fig. S1 and Table 2).

11 Interestingly, this prediction was unique to these sequences alone. Analysis of no other YopD-like 12 sequence sourced from the other genera was suggestive of an N-terminal coiled-coil. Hence, this N13 terminal segment might exclusively contribute to YopD function during Yersinia pathogenesis.

\subsection{Disruption of the N-terminal coiled-coil of YopD}

Short of solving the YopD structure, it is difficult to demonstrate that the N-terminal domain forms a coiled coil. However, if the coiled-coil is disrupted, this may lead to differences in YopD structure and function. As a first step, we therefore generated by site directed mutagenesis and allelic exchange two variant yopD alleles in cis on the virulence plasmid and coding for $\mathrm{YopD}_{\mathrm{I} 32 \mathrm{~K}}$ and $\mathrm{YopD}_{\mathrm{I} 32 \mathrm{P}}$ that were anticipated to reduced coiled-coil prediction probability from $80 \%$ to $60 \%$ or $0 \%$, respectively (Supplementary Fig. S1). In addition, we also took advantage of a previously constructed yopD mutation that codes for a poorly secreted $\operatorname{YopD}_{\Delta 23-47}$ variant that essentially lacks the N-terminal putative coiledcoil (Olsson et al., 2004).

To probe for structural differences between the wild-type and mutant proteins, we performed a limited chymotrypsin digestion of secreted YopD. Chymotrypsin was chosen because PeptideCutter 
1 (http://us.expasy.org/tools/peptidecutter) predictions suggested it should recognize only five sites evenly

2 distributed in YopD with a cleavage probability of $\leq 80 \%$ (data not shown). All secreted YopD variants

3 essentially exhibited a similar peptide fragmentation pattern, although modest alterations in the mobility

4 of smaller digested fragments were identified for $\mathrm{YopD}_{\mathrm{I} 32 \mathrm{P}}$ (Fig. 2). As an alternative, we also examined

5 for changes in YopD oligomeric state by EGS crosslinking of Yersinia secreted fractions. Crosslinking

6 was able to capture higher order structures for all three secreted YopD variants that quite possibly

7 represented dimers, trimers and tetramers (Fig. 3). However, not only was the extent of $\mathrm{YopD}_{\mathrm{I} 32 \mathrm{P}}$

8 crosslinking and/or stable oligomer formation quite obviously reduced, but their banding patterns also

9 varied from native YopD and $\operatorname{YopD}_{\mathrm{I} 32 \mathrm{~K}}$ (Fig. 3).

10 Although this combined analysis does not conclusively show that the N-terminus forms a coiled coil, 11 data from chymotrypsin digestion and probing of oligomeric state collectively favors a subtle structural 12 alteration that specifically resulted from introduction of a proline helix-breaker in the YopD $_{\mathrm{I} 32 \mathrm{P}}$ variant. In 13 contrast, the seemingly equivalent dramatic change of swapping the hydrophobic isoleucine for a charged 14 lysine in mutant $\mathrm{YopD}_{\mathrm{I} 32 \mathrm{~K}}$ did not induce any measurable structural change.

\subsection{Stable YopD N-terminal variants that maintain yop post-transcriptional control}

To facilitate our analysis of YopD function, we first of all used the method of Feldman and colleagues (Feldman et al., 2002) to demonstrate that $\mathrm{YopD}_{\text {wild type, }} \mathrm{YopD}_{\triangle 23-47}, \mathrm{YopD}_{\mathrm{I} 32 \mathrm{~K}}$ and $\mathrm{YopD}_{\mathrm{I} 32 \mathrm{P}}$ all had comparable stability in the presence of endogenous proteases (Fig. 4A). Next, we grew these bacteria in BHI broth restrictive (plus $\mathrm{Ca}^{2+}$ ) and permissive (minus $\mathrm{Ca}^{2+}$ ) for Yops production and secretion. As reported previously (Olsson et al., 2004), bacteria were slightly affected in their ability to produce YopD $_{\Delta 23-47}$ as well as other T3SS substrates including YopB, LcrV and YopE (Fig. 4B). This naturally corresponded to lower levels of their secretion into the culture supernatant; although obviously the severe reduction of $\mathrm{YopD}_{\Delta 23-47}$ secretion cannot be attributed to reduced synthesis alone (Fig. 4C). Interestingly, point mutations in this same region $\left(\mathrm{YopD}_{\mathrm{I} 32 \mathrm{~K}}\right.$ and $\left.\mathrm{YopD}_{\mathrm{I} 32 \mathrm{P}}\right)$ did not cause any obvious deviation in the 
1 synthesis and secretion profiles of YopD or other substrates, since they were all comparable to parental

2 bacteria (Fig. 4B and 4C). At least during laboratory culturing, it seems unlikely that this domain per se is

3 involved in translation control and/or as a secretion signal for recognition by the Ysc-Yop T3S apparatus

4 of Yersinia (Fig. 4C).

$5 \quad$ YopD is a well known component of yop post-transcriptional control (Chen and Anderson, 2011). This

6 is illustrated by the phenotype of Yersinia lacking YopD (Francis and Wolf-Watz, 1998; Williams and

7 Straley, 1998), which constitutively produces Yops even in the non-permissive growth media (plus $\mathrm{Ca}^{2+}$ )

8 (Fig. 4B). Critically, this strain is also temperature sensitive, being unable to grow at elevated temperature

9 regardless of $\mathrm{Ca}^{2+}$ levels (data not shown). Importantly, parent bacteria and those bacteria producing $10 \mathrm{YopD}_{\Delta 23-47}, \mathrm{YopD}_{\mathrm{I} 32 \mathrm{~K}}$ and $\mathrm{YopD}_{\mathrm{I} 32 \mathrm{P}}$ respectively, all maintained normal regulatory control, severely 11 restricting Yops synthesis in high-Ca ${ }^{2+}$ conditions (Fig. 4B). All these bacteria also displayed normal 12 calcium dependent growth phenotypes when grown at $37^{\circ} \mathrm{C}$ in $\mathrm{TMH}$ medium (data not shown). Taken 13 together, targeted disruption of the putative $\mathrm{N}$-terminal coiled-coil region of YopD does not perturb its 14 stability or capacity to maintain post-transcriptional control of Yops synthesis when bacteria are grown in 15 vitro in laboratory media.

All three mutants that produce a YopD variant with a defect in its $\mathrm{N}$-terminus still maintain a typical $\mathrm{Ca}^{2+}$-dependent Yop synthesis and secretion profile and normal growth - even though $\mathrm{YopD}_{\Delta 23-47}$ is poorly secreted. Hence, we embarked on assessing the impact of this mutants on T3SS activity. Together with two additional translocators - the highly hydrophobic YopB and the needle tip hydrophilic protein LcrV, secreted YopD contributes to contact-mediated cellular lysis via the formation of a T3S translocon pore in target cell membrane. This membrane-spanning pore maybe the conduit through which anti-host effectors gain access to the cell interior. We infected red blood cells with Yersinia and then determined the extent of cell lysis by measuring spectrophoretically the degree of hemoglobin released into the 
1 extracellular milieu. Apart from the yopD null mutant or bacteria producing $\mathrm{YopD}_{\Delta 23-47}$, other Yersinia

2 bacteria were able to induce appreciable hemoglobin release (Fig. 5A). To confirm that hemoglobin

3 release was initiated by the formation of $\mathrm{T} 3 \mathrm{~S}$ translocon pores in the erythrocyte membrane, we

4 performed an osmoprotection assay in which carbohydrates of various dimensions were used to block the

5 pores formed in erythrocyte membranes to prevent osmolysis. Critically, the smaller sized sugar raffinose,

6 with a diameter $(\phi)$ of $1.2-1.4 \mathrm{~nm}$ only blocked $\sim 10 \%$ of hemoglobin release caused by Yersinia infection

7 (Fig 5B). On the other hand, the larger sized dextrin 15 (2.2nm $\phi)$ reduced hemolysis to $\sim 50 \%$ achieved

8 in the absence of sugars, while dextran $4(3-3.5 \mathrm{~nm} \phi)$ further limited hemolysis in the range of $\sim 70 \%$

9 (Fig 5B). Importantly, all sugars blocked pores formed by parent bacteria or bacteria producing YopD $_{\mathrm{I} 32 \mathrm{~K}}$

10 or $\mathrm{YopD}_{\mathrm{I} 32 \mathrm{P}}$ to equivalent degrees. These three bacteria must therefore form similarly sized translocon

11 pores in target cell membranes.

12

$13 \quad 3.6$ T3SS function in vitro is not compromised

14

17 phagocytosis and killing. As a gauge of Yop effector translocation into eukaryotic cells, we preformed a

18 HeLa cell cytotoxicity assay. This assay is based upon the localization of the GTPase-activating protein

19 YopE in the infected host cell cytosol. Because YopE activity destabilizes host cell actin, intoxicated cells

20 will display a changed morphology from oblong to well-rounded. As expected, in as little as 30 min post-

21 infection with parental $Y$. pseudotuberculosis, a rapid morphological change in all of the infected cells

22 was observed. This was true also of bacteria producing $\mathrm{YopD}_{\mathrm{I} 32 \mathrm{~K}}$ or $\mathrm{YopD}_{\mathrm{I} 32 \mathrm{P}}$ that is indicative of a

23 functional T3SS in vitro (Fig. 6). In contrast, cell monolayer morphology was unperturbed when infected

24 with bacteria completely lacking YopD or producing the very poorly secreted $\mathrm{YopD}_{\Delta 23-47}$ variant, even

25 following prolonged incubation (>120 min) (Fig. 6). As has been reported previously (Francis and Wolf- 
1 Watz, 1998; Olsson et al., 2004), the inability of these two mutants to intoxicate HeLa cell monolayers is 2 consistent with them producing a dysfunctional T3SS.

3 To verify Yop effector translocation into epithelial cell monolayers by Yersinia producing either the

4 YopD $_{\mathrm{I} 32 \mathrm{~K}}$ or $\mathrm{YopD}_{\mathrm{I} 32 \mathrm{P}}$ variant, we performed a proteinase K-digitonin detergent solubility assay. With

5 anti-YopE and anti-YopH antiserum, we could detect equivalent levels of proteinase $\mathrm{K}$ protected and

6 detergent soluble YopE and YopH in the cytosolic fractions of HeLa cells regardless of them being

7 infected with parental bacteria or bacteria producing either $\operatorname{YopD}_{\mathrm{I} 32 \mathrm{~K}}$ or $\mathrm{YopD}_{\mathrm{I} 32 \mathrm{P}}$ (Fig. 7A). In contrast,

8 much less YopE and, to some extent YopH, were detected in cytosolic fractions of HeLa cell monolayers

9 infected with yopD null mutant or bacteria producing $\mathrm{YopD}_{\Delta 23-47}$ (Fig. 7A). Hence, Yop effector 10 tranlocation into tissue culture cells is intact in bacteria producing either $\mathrm{YopD}_{\mathrm{I} 32 \mathrm{~K}}$ or $\mathrm{YopD}_{\mathrm{I} 32 \mathrm{P}}$.

11 Pathogenic Yersinia sp. escape host cell phagocytosis through the combined action of translocated 12 anti-host effector toxins (Viboud and Bliska, 2005). Therefore, we measured the capacity of our YopD 13 mutants to resist phagocytosis and killing by J774A.1 macrophage-like immune cells. In this assay, 14 bacteria with a dysfunctional T3SS will be engulfed by the professional phagocytic cell and subsequently 15 killed by anti-microbial effectors present in the host cell cytosol. However, bacteria harboring a fully 16 functional T3SS will resist phagocytosis to permit their proliferation in the extracellular environment 17 (Bartra et al., 2001). Bacterial infections were monitored up to $6 \mathrm{~h}$ post-infection. At $2 \mathrm{~h}$ and $6 \mathrm{~h}$ post18 infection, bacteria in close association with host cell were quantified for viability by measuring colony 19 forming units. As a control, we used the translocation defective and growth restricted $\triangle y o p D$ null mutant. 20 As observed previously (Amer et al., 2011), this variant cannot resist immune cell phagocytosis and is 21 efficiently killed, which significantly lowers the recovery of viable bacteria at $2 \mathrm{~h}(P=0.015)$ and $6 \mathrm{~h}$ $22(P=0.005)$ post-infection compared to the parental strain (Fig. 7B). Bacteria producing YopD ${ }_{\Delta 23-47}$ also 23 exhibits an inferior ability to defend against phagocytosis given the lower recovery of viable bacteria after 24 6h $(P<0.0001)$ (Fig. 7B). This can be explained by an impairment of YopD secretion in vitro (see Fig. $252 \mathrm{C})$. On the other hand, bacteria producing $\mathrm{YopD}_{\mathrm{I} 32 \mathrm{~K}}$ or $\mathrm{YopD}_{\mathrm{I} 32 \mathrm{P}}$ could efficiently resist immune cell 26 engulfment as measured by extensive extracellular replication at levels equivalent to parental bacteria 
1 (Fig. 7B). These in vitro-based assays suggest that both $\mathrm{YopD}_{\mathrm{I} 32 \mathrm{~K}}$ and $\mathrm{YopD}_{\mathrm{I} 32 \mathrm{P}}$ support a fully functional

2 T3SS, despite incorporating disruptive structural mutations at their N-terminus. In contrast, a full deletion 3 of this segment leads to poor secretion of $\mathrm{YopD}_{\Delta 23-47}$, which is a serious impediment to T3SS function at 4 the zone of Yersinia-host cell contact.

5

$6 \quad 3.7$ YopD N-terminus contributes to Yersinia virulence

7

8 Obtaining YopD variants that maintain ysc-yop regulatory control and normal growth gave us the 9 opportunity to assess their virulence in an in vivo murine infection model. Oral infections of female 10

\section{Discussion}


The YopD protein is a critical component of Yersinia Ysc-Yop T3SS function. As a multi-functional 3 protein, it is essential for post-transcriptional control of yop expression (Chen and Anderson, 2011) and 4 also assembles into a translocon pore within the host cell plasma membrane through which effectors 5 might gain access to the cell interior (Costa et al., 2010; Edqvist et al., 2007; Goure et al., 2005; 6 Montagner et al., 2011; Neyt and Cornelis, 1999a; Olsson et al., 2004). It may even possess an effector 7 activity inside the target cell as a portion of YopD is also translocated (Francis and Wolf-Watz, 1998). 8 Reflecting these critical functions, YopD sequences are broadly conserved throughout the genomes of 9 human pathogenic Yersinia. Only one polymorphism (group A; G183S) separated the consensus $Y$. 10 pseudotuberculosis YPIII YopD sequence from all other YopD sequences sourced from Y. pestis isolates. 11 This degree of conservation is impressive considering that all these $Y$. pestis isolates represent 12 geographically diverse environmental reservoirs and also vary in their virulence potential. Moreover, it 13 contrasts with LcrV findings; another translocon member coded for on the same polycistronic 14 lcrGVHyopBD operon. Even among the $Y$. pestis isolates, LcrV sequence polymorphisms are 15 comparatively common (Anisimov et al., 2010). This is consistent with it being a surface exposed and 16 dominant immunogen, which may drive a greater selection pressure for diversification.

17 Comparisons between YopD sequences from the two enteropathogenic Yersinia sp. did reveal a 18 greater diversity (groups B to E). We cannot determine if any of these polymorphisms impart unique 19 structural constraints on YopD because a tertiary structure is unavailable. It is possible that some could 20 alter YopD function, however on the basis of similar studies with LcrV, we consider this to be very 21 unlikely. Even though $Y$. enterocolitica LcrV possesses 2 to 3 times more polymorphic loci then reported 22 here for YopD, it was still fully capable of supporting both in vitro and in vivo T3SS function in $Y$. pestis 23 lacking cognate LcrV (Miller et al., 2012). In view of this, changes in non essential regions of the 24 translocon scaffold are obviously reasonably well-tolerated by the Ysc-Yop T3SS. This is well supported 25 by the fact that the vast majority of identified polymorphisms either cluster to the N-terminus where a 
1 high degree of variation can still maintain efficient YopD secretion (Amer et al., 2011) or to a region 2 between residues 150 to 227 that is known to be non-essential for YopD function (Olsson et al., 2004).

3 Ample evidence confirms that coiled-coil motifs in a variety of proteins from diverse origins are 4 inherent to protein function. Inspired by this, we examined YopD sequences for recognizable coiled-coil 5 motifs. In addition to a widely predicted coiled-coil at the C-terminus of most YopD-like sequences 6 (Bröms et al., 2003; Pallen et al., 1997), we took note of a consistently predicted (albeit with low 7 probability) motif present in the N-terminus of YopD sequences solely derived from pathogenic Yersinia $8 \mathrm{sp}$. We were curious to know if this contributed to a function of YopD that is unique to Yersinia. While 9 disruption of this segment did not reveal any obvious defect in T3S as measured by in vitro assays, 10 bacteria were attenuated for virulence in an oral infection mouse model. Hence, this region of YopD 11 imparts an influence on T3SS activity that is required for disease progression in orally infected mice. In 12 the absence of a YopD structure however, we cannot say for sure that this region is an actual coiled-coil. 13 Nevertheless, introduction of an I32P mutation into YopD induced subtle alterations in the chymotrypsin 14 digestion profile and reduced its propensity for oligomerization, which is suggestive that this $\mathrm{N}$-terminal 15 sequence does confer some structural constraint on YopD. Interestingly, recently solved partial structures 16 of the YopB-like hydrophobic translocators $\mathrm{IpaB}$ and SipB from Shigella flexneri and Salmonella 17 enterica Typhimurium respectively, physically confirm the presence of an N-terminal coiled-coil (Barta 18 et al., 2012). Only with the solving of a solution structure can this also be verified for YopD.

At this stage, it is unclear what aspect of YopD function is limited by the I32K and I32P substitutions. 21 SopB from S. enterica (Knodler et al., 2011). However, we do not believe that the putative N-terminal 22 coiled-coil of YopD functions to insert the translocator into membranes. This is based on the extent of 23 contact-dependent erythrocyte lysis induced by parent and mutant strains of Yersinia was 24 indistinguishable and results from carbohydrate osmoprotection studies clearly reflected that YopD25 dependent pores formed by native YopD and the point mutants were all of similar size. Further, these 26 observations are supported by independent in vitro translocation assays that indicate efficient 
1 translocation of Yops. We interpret these data to indicate that fundamental protein-protein interactions

2 involving YopD, which ultimately dictate Yop effector translocation (Costa et al., 2010; Edqvist et al.,

3 2006; Francis et al., 2000; Hartland and Robins-Browne, 1998; Iriarte et al., 1998; Montagner et al., 2011;

4 Neyt and Cornelis, 1999a, 1999b; Sarker et al., 1998; Thorslund et al., 2011), remain intact in Yersinia

5 producing the $\mathrm{YopD}_{\mathrm{I} 32 \mathrm{~K}}$ and $\mathrm{YopD}_{\mathrm{I} 32 \mathrm{P}}$ variants. However, we cannot rule out defects in other undisclosed

6 interactions or even alterations in interaction dynamics as reasons why the point mutants are less virulent

7 than the parental bacteria.

8 Critically, these data highlight the limitations of in vitro assays. While tissue culture models of 9 infection are an essential tool, individual cell lines are invariably riddled with undefined genetic 10 mutations, possess no growth control, lack typical morphological traits and in vitro culturing methods 11 cannot reproduce the physical, chemical and biological complexities associated with the whole animal in 12 vivo environment. Thus, wherever possible it is prudent to assess biological relevance with well-designed 13 in vivo studies. In this respect, the robust immune response generated by animals at the low inoculation 14 dose of $\sim 10^{7} \mathrm{CFU} / \mathrm{ml}$ was sufficient to halt systemic disease progression and clear infections by mutant 15 bacteria producing $\mathrm{YopD}_{\mathrm{I} 32 \mathrm{~K}}$ and $\mathrm{YopD}_{\mathrm{I} 32 \mathrm{P}}$, but not by the parental bacteria that rapidly progressed to a 16 fatal septicemic infection. On the other hand, at the higher inoculation doses of $\sim 10^{8}$ to $10^{9} \mathrm{CFU} / \mathrm{ml}$, the 17 balance favored infecting bacteria. In this scenario, the sheer numbers of mutant bacteria still enabled a 18 sub-optimal T3SS to nullify an over-whelmed immune response to confer rapid and fatal systemic spread. 19 Based on the very poor secretion of $\mathrm{YopD}_{\Delta 23-47}$, it was not surprising to find that bacteria producing 20 this variant were strongly attenuated in vivo, corroborating observed in vitro defects associated with our 21 pore-forming and tissue culture translocation assays performed in this study and also previously (Olsson 22 et al., 2004). It is unclear to us why secretion of this variant is so poor. We recently identified a YopD 23 secretion signal sequence in the extreme $\mathrm{N}$-terminus that clearly lay upstream of this 23 to 47 region 24 (Amer et al., 2011). Yet, for some reason deletion of residues 23 to 47 must change the context of this 25 existing secretion signal. Future work is needed to understand this phenomenon. This is made all the more 26 curious because, at least in vitro, $\mathrm{YopD}_{\mathrm{I} 32 \mathrm{~K}}$ and $\mathrm{YopD}_{\mathrm{I} 2 \mathrm{P}}$ retain capacity for efficient $\mathrm{T} 3 \mathrm{~S}$ by Yersinia. 
1 Naturally though, it remains a possibility that this region does truly contribute to optimal temporal

2 secretion of YopD, especially during animal infections were bacteria would be expected to encounter

3 authentic T3S inducing cues that guarantee a well-orchestrated substrate secretion program. While a type

4 III substrate secretion hierarchy - ensuring that translocators are secreted before effectors - has been

5 difficult to experimentally document in Yersinia, our earlier study provides some support for a unique

6 secretion signal in the first 20 residues of YopD that may permit its ordered secretion (Amer et al., 2011).

7 Hence, the N-terminal segment harboring a putative coiled-coil may in fact be an extension of this unique 8 secretion signal.

9 Along these same lines, YopD secretion is considered an essential component of the feedback 10 inhibitory loop governing Yop synthesis control (Cambronne and Schneewind, 2002; Wulff-Strobel et al., 11 2002). It is therefore significant that bacteria producing $\operatorname{YopD}_{\Delta 23-47}$ still maintain post-transcriptional 12 control of yop-regulation despite this variant being trapped in the cytoplasm. On this note, it is probably 13 not a coincidence that this strain also produced lower levels of Yops in T3S permissive growth medium. 14 In sum, this mutant offers a research tool that in time should give better clarity to the importance of YopD 15 secretion in the maintenance of yop-regulatory control, especially since it still engages with cognate LcrH 16 chaperone to form a functional regulatory complex (Francis et al., 2000; Francis et al., 2001).

22 of $Y$. pseudotuberculosis virulence in an oral infection model. This segment therefore fulfills a role for 23 YopD that is necessary for optimal T3SS activity in defense against in vivo killing by naturally activated 24 immune cells.

\section{Acknowledgments}


This work was performed within the virtual framework of the Umeå Center for Microbial Research Linnaeus Program with financial support from the Swedish Research Council (MF, MSF), Foundation for

4 Medical Research at Umeå University (MSF) and J C Kempe Memorial Fund (TRC, AAA). We express 5 gratitude to Hans Wolf-Watz (Umeå University, Umeå, Sweden) for the gift of anti-Yops antiserum and 6 to Salah I. Farag for technical assistance.

7 Author contributions: TRC, AAA, AF and MSF designed the experiments. TRC, AAA and AF performed 8 experiments. MF and MSF provided critical reagents. TRC, AAA, AF and MSF analyzed data. TRC, AF 9 and MSF wrote the paper. All authors read, provided feedback and approved the paper. The funding 10 providers had no such involvement in any of these processes.

\section{Appendix A. Supplementary data}

Supplementary data associated with this article can be found online.

\section{References}

Achtman, M., Zurth, K., Morelli, G., Torrea, G., Guiyoule, A., Carniel, E., 1999. Yersinia pestis, the cause of plague, is a recently emerged clone of Yersinia pseudotuberculosis. Proc Natl Acad Sci U S A. $96,14043-14048$.

Aili, M., Isaksson, E.L., Carlsson, S.E., Wolf-Watz, H., Rosqvist, R., Francis, M.S., 2008. Regulation of Yersinia Yop-effector delivery by translocated YopE. Int J Med Microbiol. 298, 183-192.

Amer, A.A., Ahlund, M.K., Broms, J.E., Forsberg, A., Francis, M.S., 2011. Impact of the N-terminal secretor domain on YopD translocator function in Yersinia pseudotuberculosis type III secretion. J Bacteriol. 193, 6683-6700.

Anisimov, A.P., Dentovskaya, S.V., Panfertsev, E.A., Svetoch, T.E., Kopylov, P., Segelke, B.W., Zemla, A., Telepnev, M.V., Motin, V.L., 2010. Amino acid and structural variability of Yersinia pestis LcrV protein. Infect Genet Evol. 10, 137-145.

Barta, M.L., Dickenson, N.E., Patil, M., Keightley, A., Wyckoff, G.J., Picking, W.D., Picking, W.L., Geisbrecht, B.V., 2012. The structures of coiled-coil domains from type III secretion system translocators reveal homology to pore-forming toxins. J Mol Biol. 417, 395-405. 
Bartra, S., Cherepanov, P., Forsberg, A., Schesser, K., 2001. The Yersinia YopE and YopH type III effector proteins enhance bacterial proliferation following contact with eukaryotic cells. BMC Microbiol. 1, 22.

Bölin, I., Wolf-Watz, H., 1984. Molecular cloning of the temperature-inducible outer membrane protein 1 of Yersinia pseudotuberculosis. Infect Immun. 43, 72-78.

Bröms, J.E., Forslund, A.-L., Forsberg, A., Francis, M.S., 2003. Dissection of homologous translocon operons reveals a distinct role for YopD in type III secretion by Yersinia pseudotuberculosis. Microbiology. 149, 2615-2626.

Burkhard, P., Stetefeld, J., Strelkov, S.V., 2001. Coiled coils: a highly versatile protein folding motif. Trends Cell Biol. 11, 82-88.

Cambronne, E.D., Schneewind, O., 2002. Yersinia enterocolitica type III secretion: yscM1 and yscM2 regulate yop gene expression by a posttranscriptional mechanism that targets the 5' untranslated region of yop mRNA. J Bacteriol. 184, 5880-5893.

Chen, Y., Anderson, D.M., 2011. Expression hierarchy in the Yersinia type III secretion system established through YopD recognition of RNA. Mol Microbiol. 80, 966-980.

Cohen, C., Parry, D.A., 1990. Alpha-helical coiled coils and bundles: how to design an alpha-helical protein. Proteins. 7, 1-15.

Cornelis, G.R., 2006. The type III secretion injectisome. Nat Rev Microbiol. 4, 811-825.

Cornelis, G.R., Boland, A., Boyd, A.P., Geuijen, C., Iriarte, M., Neyt, C., Sory, M.P., Stainier, I., 1998. The virulence plasmid of Yersinia, an antihost genome. Microbiol Mol Biol Rev. 62, 1315-1352.

Costa, T.R., Edqvist, P.J., Broms, J.E., Ahlund, M.K., Forsberg, A., Francis, M.S., 2010. YopD selfassembly and binding to LcrV facilitate type III secretion activity by Yersinia pseudotuberculosis. J Biol Chem. 285, 25269-25284.

Daniell, S.J., Delahay, R.M., Shaw, R.K., Hartland, E.L., Pallen, M.J., Booy, F., Ebel, F., Knutton, S., Frankel, G., 2001. Coiled-coil domain of enteropathogenic Escherichia coli type III secreted protein EspD is involved in EspA filament-mediated cell attachment and hemolysis. Infect Immun. 69, 40554064.

Delahay, R.M., Frankel, G., 2002. Coiled-coil proteins associated with type III secretion systems: a versatile domain revisited. Mol Microbiol. 45, 905-916.

Delahay, R.M., Knutton, S., Shaw, R.K., Hartland, E.L., Pallen, M.J., Frankel, G., 1999. The coiled-coil domain of EspA is essential for the assembly of the type III secretion translocon on the surface of enteropathogenic Escherichia coli. J Biol Chem. 274, 35969-35974.

Edqvist, P.J., Aili, M., Liu, J., Francis, M.S., 2007. Minimal YopB and YopD translocator secretion by Yersinia is sufficient for Yop-effector delivery into target cells. Microbes Infect. 9, 224-233.

Edqvist, P.J., Bröms, J.E., Betts, H.J., Forsberg, ̊̊., Pallen, M.J., Francis, M.S., 2006. Tetratricopeptide repeats in the type-III-secretion chaperone, LcrH: their role in substrate binding and secretion. Mol Microbiol. 59, 31-44.

Erhardt, M., Namba, K., Hughes, K.T., 2010. Bacterial nanomachines: the flagellum and type III injectisome. Cold Spring Harb Perspect Biol. 2, a000299.

Feldman, M.F., Muller, S., Wuest, E., Cornelis, G.R., 2002. SycE allows secretion of YopE-DHFR hybrids by the Yersinia enterocolitica type III Ysc system. Mol Microbiol. 46, 1183-1197. 
Francis, M.S., Aili, M., Wiklund, M.L., Wolf-Watz, H., 2000. A study of the YopD-LcrH interaction from Yersinia pseudotuberculosis reveals a role for hydrophobic residues within the amphipathic domain of YopD. Mol Microbiol. 38, 85-102.

Francis, M.S., Lloyd, S.A., Wolf-Watz, H., 2001. The type III secretion chaperone LcrH co-operates with YopD to establish a negative, regulatory loop for control of Yop synthesis in Yersinia pseudotuberculosis. Mol Microbiol. 42, 1075-1093.

Francis, M.S., Wolf-Watz, H., 1998. YopD of Yersinia pseudotuberculosis is translocated into the cytosol of HeLa epithelial cells: evidence of a structural domain necessary for translocation. Mol Microbiol. 29, 799-813.

Galan, J.E., Wolf-Watz, H., 2006. Protein delivery into eukaryotic cells by type III secretion machines. Nature. 444, 567-573.

Gazi, A.D., Bastaki, M., Charova, S.N., Gkougkoulia, E.A., Kapellios, E.A., Panopoulos, N.J., Kokkinidis, M., 2008. Evidence for a coiled-coil interaction mode of disordered proteins from bacterial type III secretion systems. J Biol Chem. 283, 34062-34068.

Gemski, P., Lazere, J.R., Casey, T., Wohlhieter, J.A., 1980. Presence of a virulence-associated plasmid in Yersinia pseudotuberculosis. Infect Immun. 28, 1044-1047.

Gophna, U., Ron, E.Z., Graur, D., 2003. Bacterial type III secretion systems are ancient and evolved by multiple horizontal-transfer events. Gene. 312, 151-163.

Goure, J., Broz, P., Attree, O., Cornelis, G.R., Attree, I., 2005. Protective anti-V antibodies inhibit Pseudomonas and Yersinia translocon assembly within host membranes. J Infect Dis. 192, 218-225.

Grabenstein, J.P., Marceau, M., Pujol, C., Simonet, M., Bliska, J.B., 2004. The response regulator PhoP of Yersinia pseudotuberculosis is important for replication in macrophages and for virulence. Infect Immun. 72, 4973-4984.

Grigoryan, G., Keating, A.E., 2008. Structural specificity in coiled-coil interactions. Curr Opin Struct Biol. 18, 477-483.

Håkansson, S., 1995. YopB-mediated translocation of Yops and the YpkA Ser/Thr kinase of Yersinia. $\mathrm{PhD}$ Thesis, Umeå, Umeå University, Sweden.

Håkansson, S., Bergman, T., Vanooteghem, J.C., Cornelis, G., Wolf-Watz, H., 1993. YopB and YopD constitute a novel class of Yersinia Yop proteins. Infect Immun. 61, 71-80.

Hamad, M.A., Nilles, M.L., 2007. Structure-function analysis of the C-terminal domain of LcrV from Yersinia pestis. J Bacteriol. 189, 6734-6739.

Hartland, E.L., Robins-Browne, R.M., 1998. In vitro association between the virulence proteins, YopD and YopE, of Yersinia enterocolitica. FEMS Microbiol Lett. 162, 207-213.

Higuchi, R., 1989. Using PCR to engineer DNA. in Erlich, H.A. (Ed.), PCR Technology: Principles and applications for DNA amplification. Stockton Press, New York, pp. 61-70.

Holmström, A., Pettersson, J., Rosqvist, R., Håkansson, S., Tafazoli, F., Fällman, M., Magnusson, K.E., Wolf-Watz, H., Forsberg, A. 1997. YopK of Yersinia pseudotuberculosis controls translocation of Yop effectors across the eukaryotic cell membrane. Mol Microbiol. 24, 73-91.

Iriarte, M., Sory, M.P., Boland, A., Boyd, A.P., Mills, S.D., Lambermont, I., Cornelis, G.R., 1998. TyeA, a protein involved in control of Yop release and in translocation of Yersinia Yop effectors. EMBO J. $17,1907-1918$.

Knodler, L.A., Ibarra, J.A., Perez-Rueda, E., Yip, C.K., Steele-Mortimer, O., 2011. Coiled-coil domains enhance the membrane association of Salmonella type III effectors. Cell Microbiol. 13, 1497-1517. 
Lawton, D.G., Longstaff, C., Wallace, B.A., Hill, J., Leary, S.E., Titball, R.W., Brown, K.A., 2002. Interactions of the type III secretion pathway proteins LcrV and LcrG from Yersinia pestis are mediated by coiled-coil domains. J Biol Chem. 277, 38714-38722.

Liu, J., Rost, B., 2001. Comparing function and structure between entire proteomes. Protein Sci. 10, 1970-1979.

Lupas, A., Van Dyke, M., Stock, J., 1991. Predicting coiled coils from protein sequences. Science. 252, 1162-1164.

Miller, N.C., Quenee, L.E., Elli, D., Ciletti, N.A., Schneewind, O., 2012. Polymorphisms in the $l c r V$ gene of Yersinia enterocolitica and their effect on plague protective immunity. Infect Immun. 80, 15721582.

Milton, D.L., O'Toole, R., Horstedt, P., Wolf-Watz, H., 1996. Flagellin A is essential for the virulence of Vibrio anguillarum. J Bacteriol. 178, 1310-1319.

Montagner, C., Arquint, C., Cornelis, G.R., 2011. Translocators YopB and YopD from Yersinia form a multimeric integral membrane complex in eukaryotic cell membranes. J Bacteriol. 193, 6923-6928.

Neyt, C., Cornelis, G.R., 1999a. Insertion of a Yop translocation pore into the macrophage plasma membrane by Yersinia enterocolitica: requirement for translocators YopB and YopD, but not LcrG. Mol Microbiol. 33, 971-981.

Neyt, C., Cornelis, G.R., 1999b. Role of SycD, the chaperone of the Yersinia Yop translocators YopB and YopD. Mol Microbiol. 31, 143-156.

Olsson, J., Edqvist, P.J., Bröms, J.E., Forsberg, A., Wolf-Watz, H., Francis, M.S., 2004. The YopD translocator of Yersinia pseudotuberculosis is a multifunctional protein comprised of discrete domains. J Bacteriol. 186, 4110-4123.

Pallen, M.J., Dougan, G., Frankel, G., 1997. Coiled-coil domains in proteins secreted by type III secretion systems. Mol Microbiol. 25, 423-425.

Reed, L.J., Muench, H., 1938. A simple method for estimating fifty percent endpoints. Am J Hyg. 27, 493-497.

Rose, A., Schraegle, S.J., Stahlberg, E.A., Meier, I., 2005. Coiled-coil protein composition of 22 proteomes--differences and common themes in subcellular infrastructure and traffic control. BMC Evol Biol. 5, 66.

Rosqvist, R., Forsberg, Å., Wolf-Watz, H., 1991. Intracellular targeting of the Yersinia YopE cytotoxin in mammalian cells induces actin microfilament disruption. Infect Immun. 59, 4562-4569.

Sarker, M.R., Neyt, C., Stainier, I., Cornelis, G.R., 1998. The Yersinia Yop virulon: LcrV is required for extrusion of the translocators YopB and YopD. J Bacteriol. 180, 1207-1214.

Schubot, F.D., Jackson, M.W., Penrose, K.J., Cherry, S., Tropea, J.E., Plano, G.V., Waugh, D.S., 2005. Three-dimensional structure of a macromolecular assembly that regulates type III secretion in Yersinia pestis. J Mol Biol. 346, 1147-1161.

Simon, R., Priefer, U., Pühler, A., 1983. A broad host range mobilisation system for in vivo genetic engineering: transposon mutagenesis in Gram negative bacteria. Nature Biotechnology. 1, 784-791.

Skurnik, M., Peippo, A., Ervela, E., 2000. Characterization of the O-antigen gene clusters of Yersinia pseudotuberculosis and the cryptic O-antigen gene cluster of Yersinia pestis shows that the plague bacillus is most closely related to and has evolved from $Y$. pseudotuberculosis serotype O:1b. Mol Microbiol. 37, 316-330. 
1 Straley, S.C., Bowmer, W.S., 1986. Virulence genes regulated at the transcriptional level by Ca2+ in

2 Yersinia pestis include structural genes for outer membrane proteins. Infect Immun. 51, 445-454.

3 Tampakaki, A.P., Fadouloglou, V.E., Gazi, A.D., Panopoulos, N.J., Kokkinidis, M., 2004. Conserved 4 features of type III secretion. Cell Microbiol. 6, 805-816.

5 Tengel, T., Sethson, I., Francis, M.S., 2002. Conformational analysis by CD and NMR spectroscopy of a 6 peptide encompassing the amphipathic domain of YopD from Yersinia. Eur J Biochem. 269, 365973668 .

8 Thorslund, S.E., Edgren, T., Pettersson, J., Nordfelth, R., Sellin, M.E., Ivanova, E., Francis, M.S., 9 Isaksson, E.L., Wolf-Watz, H., Fallman, M., 2011. The RACK1 signaling scaffold protein selectively 10 interacts with Yersinia pseudotuberculosis virulence function. PLoS One. 6, e16784.

Troisfontaines, P., Cornelis, G.R., 2005. Type III secretion: more systems than you think. Physiology (Bethesda). 20, 326-339.

Viboud, G.I., Bliska, J.B., 2005. Yersinia outer proteins: role in modulation of host cell signaling responses and pathogenesis. Annu Rev Microbiol. 59, 69-89.

Williams, A.W., Straley, S.C., 1998. YopD of Yersinia pestis plays a role in negative regulation of the low-calcium response in addition to its role in translocation of Yops. J Bacteriol. 180, 350-358.

Wren, B.W., 2003. The yersiniae--a model genus to study the rapid evolution of bacterial pathogens. Nat Rev Microbiol. 1, 55-64.

Wulff-Strobel, C.R., Williams, A.W., Straley, S.C., 2002. LcrQ and SycH function together at the Ysc type III secretion system in Yersinia pestis to impose a hierarchy of secretion. Mol Microbiol. 43, 411423. 


\section{Table 1}

3 Bacterial strains and plasmids used in this study.

4

\begin{tabular}{|c|c|c|}
\hline Strain or plasmid & Relevant genotype or phenotype & Source or reference \\
\hline \multicolumn{3}{|l|}{ Strain } \\
\hline \multicolumn{3}{|l|}{ E. coli } \\
\hline TOP10 & $\begin{array}{l}\mathrm{F}^{-}, \text {mcrA, } \Delta(m r r-h s d R M S-m c r B C), \\
\phi 80 l a c Z \Delta \mathrm{M} 15, \Delta l a c X 74, \operatorname{rec} A 1, \text { araD } 139,(\Delta a r a- \\
\text { leu }) 7697, \text { galU, galK, rpsL }\left(\mathrm{Sm}^{\mathrm{R}}\right), \text { endA1, nup }\end{array}$ & Life Technologies \\
\hline DH5 & $\begin{array}{l}\mathrm{F}^{-}, \text {recA } 1, \text { endA } 1, \text { hsdR } 17, \text { supE } 44, \text { thi-1, gyrA } 96 \text {, } \\
\text { relA } 1\end{array}$ & Stratagene \\
\hline 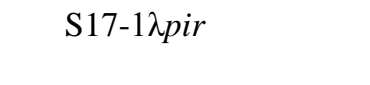 & $\begin{array}{l}\text { recA, thi, pro, hsdR-M } M^{+}, \mathrm{Sm}^{\mathrm{R}},<\mathrm{RP} 4: 2- \\
\mathrm{Tc}: \mathrm{Mu}: \mathrm{Ku}: \operatorname{Tn} 7>\mathrm{Tp}^{\mathrm{R}}\end{array}$ & (Simon et al., 1983) \\
\hline \multicolumn{3}{|l|}{ Y.pseudotuberculosis } \\
\hline YPIII/pIB102 & yadA::Tn5, $\mathrm{Km}^{\mathrm{R}}$ (parent) & (Bölin and Wolf-Watz, 1984) \\
\hline YPIII/pIB621 & pIB102, YopD ${ }_{\Delta 4-303}, \mathrm{Km}^{\mathrm{R}}$ & (Francis and Wolf-Watz, 1998) \\
\hline YPIII/pIB605 & pIB102, YopD & (Håkansson, 1995) \\
\hline YPIII/pIB60501 & pIB102, YopD ${ }_{\mathrm{I} 32 \mathrm{~K}}, \mathrm{Km}^{\mathrm{R}}$ & This study \\
\hline YPIII/pIB60502 & pIB102, YopD $D_{132 \mathrm{P}}, \mathrm{Km}^{\mathrm{R}}$ & This study \\
\hline YPIII/pIB 155 & pIB102, $\Delta y о p K, \mathrm{Km}^{\mathrm{R}}$ & (Holmström et al., 1997) \\
\hline YPIII/pIB155D & pIB155, YopD ${ }_{\Delta 4-303}, \mathrm{Km}^{\mathrm{R}}$ & (Francis and Wolf-Watz, 1998) \\
\hline YPIII/pIB155-605 & pIB155, YopD ${ }_{\Delta 23-47}, \mathrm{Km}^{\mathrm{R}}$ & (Olsson et al., 2004) \\
\hline YPIII/pIB155-60501 & pIB155, YopD ${ }_{\text {I32K }}, \mathrm{Km}^{\mathrm{R}}$ & This study \\
\hline YPIII/pIB155-60502 & pIB155, YopD ${ }_{\text {I32P }}, \mathrm{Km}^{\mathrm{R}}$ & This study \\
\hline \multicolumn{3}{|l|}{ Plasmids } \\
\hline pCR4®-TOPO & TA cloning vector, $\mathrm{Km}^{\mathrm{R}}, \mathrm{Amp}^{\mathrm{R}}$ & Life Technologies \\
\hline pDM4 & Suicide plasmid carrying $\operatorname{sac} B R, \mathrm{Cml}^{\mathrm{R}}$ & (Milton et al., 1996) \\
\hline pSF013 & $\begin{array}{l}\text { pDM4 containing a XhoI/XbaI } 470 \mathrm{bp} \text { PCR } \\
\text { product of the allele for } \mathrm{YopD}_{\mathrm{I} 32 \mathrm{~K}}, \mathrm{Cml}^{\mathrm{R}}\end{array}$ & This study \\
\hline pSF021 & $\begin{array}{l}\text { pDM4 containing a Xhol/Xbal } 470 \text { bp PCR } \\
\text { product of the allele for } \text { YopD }_{132 \mathrm{P}}, \mathrm{Cml}^{\mathrm{R}}\end{array}$ & This study \\
\hline
\end{tabular}




\section{Table 2}

2 Amino acid identity to YopD from Yersinia pseudotuberculosis strain YPIII among the YopD family of translocator proteins and their predicted 3 coiled-coil segments

4

\begin{tabular}{|c|c|c|c|c|c|c|c|}
\hline Species $^{\mathrm{a}}$ & Strain & $\begin{array}{l}\text { Accession number }{ }^{b} \text { (YopD } \\
\text { homologue) }\end{array}$ & Size (aa) & $\begin{array}{l}\text { Percent identity to } \\
\text { YPIII_YopD ( } \% \\
\text { amino acid coverage) }\end{array}$ & $\begin{array}{l}\text { Expect } \\
\text { (E)-value }\end{array}$ & $\begin{array}{l}\text { YopD type } \\
\text { (number of }^{\text {database entries) }}{ }^{\mathrm{c}}\end{array}$ & $\begin{array}{l}\text { Coiled-coil } \\
\text { segments }^{\mathrm{d}}\end{array}$ \\
\hline Y.pseudotuberculosis & YPIII* $^{*}$ & AAA72322 (YPIII_YopD) & 306 & $\mathrm{n} / \mathrm{a}$ & 0 & $\mathrm{n} / \mathrm{a}$ & 31-44 (unclear) \\
\hline Y. pseudotuberculosis & $\begin{array}{l}\text { IP32953 } \\
\text { PB1/+ }\end{array}$ & $\begin{array}{l}\text { YP_068463 } \\
\text { YP_001874673 }\end{array}$ & 306 & $99.7(100)$ & 0 & A (at least 2) & $\begin{array}{l}250-275 \\
31-44 \text { (unclear) } \\
250-275\end{array}$ \\
\hline$Y$. pestis & $\begin{array}{l}\text { CO92* } \\
\text { Kim10+ } \\
\text { Pestoides F } \\
\text { 91001 (biovar Microtus) } \\
\text { UG05-0454 (biovar Antiqua) } \\
\text { MG05-1020 (biovar Orientalis) } \\
\text { K1973002 (biovar Mediaevalis) }\end{array}$ & $\begin{array}{l}\text { NP_395162 (YopD) } \\
\text { NP_857754 (YopD) } \\
\text { YP_001154618 (YopD) } \\
\text { NP_995383 (YopD) } \\
\text { ZP_02307382 (YopD) } \\
\text { ZP_02314225 } \\
\text { ZP_02318589 }\end{array}$ & 306 & $99.7(100)$ & 0 & A (many) & $\begin{array}{l}31-44 \text { (unclear) } \\
250-275\end{array}$ \\
\hline Y. enterocolitica & $\begin{array}{l}\text { W22703* (serotype 0:9) } \\
\text { 105.5R(r) }\end{array}$ & $\begin{array}{l}\text { AAD16812 (YopD) } \\
\text { YP_004424912 (YopD) }\end{array}$ & 306 & $98.0(100)$ & 0 & $\mathrm{~B}$ (at least 3) & $\begin{array}{l}31-44 \text { (unclear) } \\
250-275\end{array}$ \\
\hline Y. enterocolitica & 09-856 (serotype O:5,27) & ACX69982 (YopD) & 306 & $97.7(100)$ & 0 & $\mathrm{C}(1)$ & $\begin{array}{l}31-44 \text { (unclear) } \\
250-275\end{array}$ \\
\hline Y. enterocolitica & 8081 (serotype 0:8) & YP_001004066 (YopD) & 306 & $97.4(100)$ & 0 & $\mathrm{D}(1)$ & $\begin{array}{l}31-44 \text { (unclear) } \\
250-275\end{array}$ \\
\hline Y. enterocolitica & $\begin{array}{l}\text { YE96 (serotype 0:9) } \\
\text { A127/90* (serotype 0:8) }\end{array}$ & $\begin{array}{l}\text { AAB31852 } \\
\text { NP_783662 }\end{array}$ & 306 & $97.1(100)$ & 0 & $\mathrm{E}$ (at least 3) & $\begin{array}{l}31-44 \text { (unclear) } \\
250-275\end{array}$ \\
\hline A. veronii & HM21* (biovar sobria) & ABP51935(AopD) & 298 & $49.3(90)$ & $6 \mathrm{E}-84$ & $\mathrm{n} / \mathrm{a}$ & $\begin{array}{l}84-111 \text { (unclear) } \\
241-266\end{array}$ \\
\hline A. hydrophila & AH-1 & AAR26342 (AopD) & 299 & $47.3(88)$ & $1 \mathrm{E}-78$ & $\mathrm{n} / \mathrm{a}$ & none \\
\hline A. salmonicida & A $449^{*}$ & YP_001144286 (AopD) & 298 & $45.7(95)$ & $2 \mathrm{E}-78$ & $\mathrm{n} / \mathrm{a}$ & $230-263$ \\
\hline Ph. asymbiotica & ATCC 43949 & $\begin{array}{l}\text { YP_003039900 } \\
\text { (PAU_01063) }\end{array}$ & 297 & $46.2(91)$ & $3 \mathrm{E}-74$ & $\mathrm{n} / \mathrm{a}$ & $\begin{array}{l}\text { 62-76(unclear) } \\
\text { 243-265(unclear) }\end{array}$ \\
\hline Ph. luminescens & W14* & AAO18056 (LopD) & 294 & $46.5(87)$ & $2 \mathrm{E}-71$ & $\mathrm{n} / \mathrm{a}$ & none \\
\hline P. aeruginosa & $\mathrm{PAO}^{*}$ & NP_250400 (PopD) & 295 & $41.3(86)$ & $2 \mathrm{E}-64$ & $\mathrm{n} / \mathrm{a}$ & none \\
\hline V. harveyi & HY01 & ZP_01985143 (VopD) & 334 & $29.2(90)$ & $2 \mathrm{E}-24$ & $\mathrm{n} / \mathrm{a}$ & $\begin{array}{l}131-156 \\
264-318\end{array}$ \\
\hline V. parahaemolyticus & RIMD $2210633^{*}$ & NP_798035 (VopD) & 334 & $31.3(70)$ & $3 \mathrm{E}-19$ & $\mathrm{n} / \mathrm{a}$ & $\begin{array}{l}128-154 \\
252-317\end{array}$ \\
\hline Pb. damselae & CIP $102761^{*}$ & $\begin{array}{l}\text { ZP_06157736 } \\
\text { (VDA_000190) }\end{array}$ & 286 & $27.8(70)$ & $3 \mathrm{E}-15$ & $\mathrm{n} / \mathrm{a}$ & $\begin{array}{l}121-160 \\
216-238 \\
258-278 \text { (unclear) }\end{array}$ \\
\hline
\end{tabular}


a Y, Yersinia; A, Aeromonas; Ph, Photorhabdus; P, Pseudomonas; V, Vibrio; Pb, Photobacterium

2 b NCBI Reference Sequence

3 c see Figure 1 for a ClustalW alignment of representative sequences

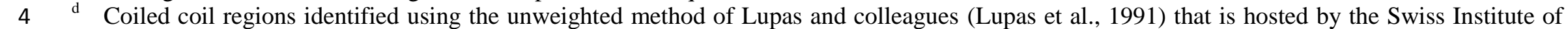

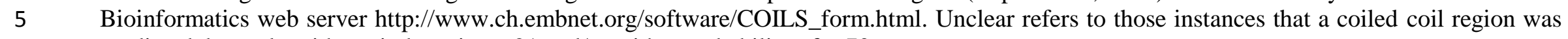
6 predicted, but only with a window size $<21$ and/or with a probability of $<70 \%$

* Coiled- coil prediction output profiles of those marked are available for download and viewing online as Supplementary Fig. S1. 


\section{Figure legends}

Fig. 1. Amino acid sequence variation among YopD proteins. A Blastp (protein-protein BLAST) using YopD query sequence from $Y$. pseudotuberculosis YPIII (designated YPIII_YopD) was used to identify all related alleles encoded by Yersinia (taxonomy identity: 629). This search identified five additional groups (designated A to E) of different YopD sequences. Representatives of these sequences were then aligned with ClustalW. YopD produced by other $Y$. pseudotuberculosis strains and by $Y$. pestis are identical with YPIII_YopD bar a sole substitution of Glycine at position 183 for Serine (sequence group A). In contrast, YopD produced by different $Y$. enterocolitica strains possess subtly more variation that can be further divided into four additional sequence groups; group B (6 differences - K27G, I32V, T113S, E172D, G183S and I185A), group C (7 differences - Q17R, K27G, I32V, T113S, E172D, G183S and I185A), group D (8 differences - L18I, K27G, I32V, T111A, E172D, G183S, I185T and G186S) and group E (9 differences - L18I, K27G, I32V, T111A, E172D, M179L, G183S, I185T and G186S). Identical residues are represented by the asterisk (*) symbol. Residues predicted to form a putative transmembrane domain are indicated with a bold black underscore. Predicted coiled coil regions in the Nterminus and C-terminus are highlighted with a dashed line. Vertical filled bars indicate the heptad periodicity of the individual segments with the predominately hydrophobic amino acids at the ' $a$ ' (light gray) and ' $d$ ' (dark gray) positions highlighted. Moreover, the isoleucine at position 32 mutated in this study to specifically disrupt the $\mathrm{N}$-terminal coiled-coil is identified by an arrow. The C-terminal amphipathic $\alpha$-helix (Costa et al., 2010; Tengel et al., 2002) is emphasized with a solid gray underscore. In several other T3SSs belonging to the Ysc-Yop clade (Troisfontaines and Cornelis, 2005), homologues to YopD exist. Strictly conserved residues found in all analyzed YopD-like sequences are indicated by the hash (\#) symbol. Consult Table 2 for further details including individual bacterial names, NCBI accession numbers and sequence relatedness. 
3 Fig. 2. Limited chymotrypsin digestion of secreted YopD variants. Secreted YopD prepared from 4 cleared culture supernatants of bacteria grown in BHI media depleted of calcium were incubated with (+) 5 or without (-) $10 \mu \mathrm{g} / \mathrm{ml}$ chymotrypsin (CT) for $30 \mathrm{~min}$ prior to trichloroacetic acid precipitation. Samples

6 were fractionated on a regular 18\% acrylamide SDS-PAGE and YopD digestion products identified with 7 polyclonal rabbit anti-YopD. Lanes: Parent $\left(\right.$ YopD $\left._{\mathrm{wt}}\right)$, YPIII/pIB102; YopD ${ }_{\Delta 23-47}$, YPIII/pIB605; 8 YopD $_{\mathrm{I32K}}, \mathrm{YPIII} / \mathrm{pIB} 60501$; YopD $\mathrm{I}_{\mathrm{I32}}$, YPIII/pIB60502. Note the absence of signal in the $\mathrm{YopD}_{\Delta 23-47}$ lane 9 because this product is poorly secreted.

Fig. 3. Oligomeric state of secreted YopD. Secreted YopD prepared from cleared culture supernatants 12 of bacteria grown in BHI media depleted of calcium were cross-linked with $(+)$ or without $(-)$ membrane 13 permeable $0.5 \mathrm{mM}$ EGS. Samples were separated by $12 \%$ acrylamide SDS-PAGE and immunoblotted 14 with polyclonal rabbit anti-YopD antiserum. The positions of the protein standards with their approximate 15 molecular mass $(\mathrm{kDa})$ are marked at left. Asterisks at right mark protein bands that represent higher order 16 YopD oligomers. After chemiluminescence detection, the left panel indicates short exposure (15sec) and

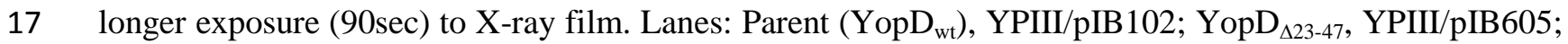

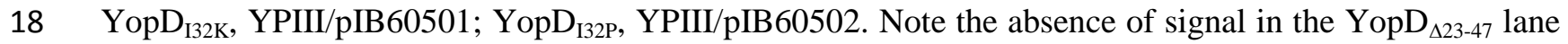
19 because this product is poorly secreted.

Fig. 4. YopD variants are stable and maintain Yops synthesis and secretion control. (A) Yersinia 23 pseudotuberculosis was grown in $\mathrm{BHI}$ media under non-inducing conditions $\left(+\mathrm{Ca}^{2+}\right)$ at $37^{\circ} \mathrm{C}$. At time 24 point 0 , chloramphenicol was added to stop de novo protein synthesis and aliquots were taken at different 25 time points (0 to 60min). Resistance to degradation by endogenous proteases was determined by Western- 
1 blot using a polyclonal anti-YopD antiserum. (B) Bacteria were grown in vitro in BHI media under Yops-

2 restrictive $\left(+\mathrm{Ca}^{2+}\right)$ or Yops-permissive $\left(-\mathrm{Ca}^{2+}\right)$ conditions. Synthesized Yop proteins associated with the

3 bacterial cell pellet (B) or secreted into the cleared culture supernatant (C) was analyzed by

4 immunobloting using polyclonal rabbit anti-YopB, anti-LcrV, anti-YopD and anti YopE antiserum.

5 Lanes: Parent $\left(\mathrm{YopD}_{\mathrm{wt}}\right)$, YPIII/pIB102; $\Delta y o p D$ null mutant $\left(\mathrm{YopD}_{\Delta 4-303}\right)$, YPIII/pIB621; YopD ${ }_{\Delta 23-47}$,

6 YPIII/pIB605; YopD ${ }_{\mathrm{I} 2 \mathrm{~K}}$, YPIII/pIB60501; YopD ${ }_{\mathrm{I} 32 \mathrm{P}}$, YPIII/pIB60502. The predicted molecular weight of

7 each identified Yop is specified in parentheses.

8

Fig. 5. Contact dependent erythrocyte hemolysis and translocon pore formation by $Y$. pseudotuberculosis. Erythrocyte lysis caused by $Y$. pseudotuberculosis parent and a series of yopD mutants disrupted in the $\mathrm{N}$-terminal putative coiled-coil domain was determined by hemoglobin release. Horse red blood cells were infected in the absence (A) or presence (B) of carbohydrates of different sizes (raffinose $(1.2-1.4 \mathrm{~nm} \phi)$, dextrin $15(2.2 \mathrm{~nm} \phi)$, and dextran 4 (3-3.5nm $\phi))$. To increase the efficiency of pore formation, the $\triangle y o p K$ null mutant (YPIII/pIB155) (Holmström et al., 1997) was used as the parent strain into which all yopD mutations were introduced. The extent of osmoprotection afforded by the different size sugars is represented as the percentage of lytic activity occurring in the absence of sugars. Strains: $\Delta y o p K$ null mutant (parent) producing native YopD (YopD $\left.{ }_{w t}\right), Y P I I I / p I B 155 ; \Delta y o p K$ with fulllength $\Delta y o p D$ null mutant $\left(\mathrm{YopD}_{\Delta 4-303}\right)$, YPIII/pIB155D; $\Delta y o p K$ with $\mathrm{YopD}_{\Delta 23-47}, \mathrm{YPIII} / \mathrm{pIB} 155-605$; syopK with YopD $_{132 \mathrm{~K}}$, YPIII/pIB155-60501; $\Delta y o p K$ with YopD $_{\mathrm{I} 22 \mathrm{P}}$, YPIII/pIB155-60502. Uninfected refers to a mock infection in the absence of bacteria to assay for autolysis of red blood cells.

Fig. 6. Yersinia-mediated cytotoxicity against epithelial cell monolayers. HeLa cell monolayers were infected with various $Y$. pseudotuberculosis strains. At 30, 60 and 120min post-infection, the eukaryotic cell morphology was captured by a phase-contrast microscope containing a digital camera adaption. Intoxication of HeLa cells by the translocation of the GTPase activating protein YopE cytotoxin causes a 
1 morphological change in cell shape from oblong to rounded. HeLa cells not intoxicated with YopE show

2 normal cell morphology. Strains: Parent $\left(\mathrm{YopD}_{\mathrm{wt}}\right)$, YPIII/pIB102; $\Delta y o p D$ null mutant $\left(\mathrm{YopD}_{\Delta 4-303}\right)$,

3 YPIII/pIB621; YopD Y23-47, $_{1}$ YPIII/pIB605; YopD ${ }_{\mathrm{I32K}}, \quad$ YPIII/pIB60501; $\quad$ YopD $_{\mathrm{I32P}}, \quad$ YPIII/pIB60502.

4 Uninfected refers to a mock infection in the absence of bacteria to ensure that cell monolayer morphology

5 is not influence by any other parameter within the conditions assayed.

6

$7 \quad$ Fig. 7. Disruption of YopD N-terminal coiled-coil does not compromise in vitro T3SS activity. (A)

8 Protease protection and digitonin extraction of translocated Yersinia effector proteins present in the 9 cytosol of infected HeLa cell monolayers. Fractions were subjected to western blot analysis using rabbit 10 anti-YopE and goat anti-YopH antiserum and purified mouse anti-ERK1 (BD Pharmingen). Translocated 11 proteins reflected the difference between protein levels observed in digitonin-treated HeLa cells and non12 treated HeLa cells. The anti-YopH antiserum cross-reacts with unknown antigens of eukaryote cell origin. 13 The YopH protein also displays enhanced resistance to proteinase K digestion. (B) Y. pseudotuberculosis 14 strains were used to infect murine macrophage-like J774-1 cells. Bacterial cells with a compromised 15 T3SS were more rapidly phagocytosed and killed by these immune cells. Bacterial survival as measured 16 by $\mathrm{CFU} / \mathrm{ml}$ was determined at $2 \mathrm{~h}$ and $6 \mathrm{~h}$ post-infection. The results are expressed as a mean of 5 17 independent assays \pm the standard deviation. Bacteria producing $\mathrm{YopD}_{\mathrm{I} 32 \mathrm{~K}}$ and $\mathrm{YopD}_{\mathrm{I} 32 \mathrm{P}}$ show comparable 18 viability to parental bacteria after $6 \mathrm{~h}$. The asterisks $(* *$ or $* * *)$ indicate that YopD variants were 19 statistically less viable (two-tailed parametric Mann-Whitney $U$ test, $P<0.05$ ) than parental bacteria. 20 Strains: Parent $\left(\mathrm{YopD}_{\mathrm{wt}}\right)$, YPIII/pIB102; $\Delta y$ opD null mutant $\left(\mathrm{YopD}_{\Delta 4-303}\right)$, YPIII/pIB621; YopD ${ }_{\Delta 23-47}$, 21 YPIII/pIB605; YopD ${ }_{\mathrm{I} 32 \mathrm{~K}}$, YPIII/pIB60501; YopD ${ }_{\mathrm{I} 32 \mathrm{P}}$, YPIII/pIB60502.

23 Fig. 8. An intact YopD N-terminus is essential for full Yersinia virulence. Overnight cultures of $Y$. 24 pseudotuberculosis parent and mutant bacteria were harvested and then serially diluted to $10^{9}, 10^{8}$ and $10^{7}$ $25 \mathrm{CFU} / \mathrm{ml}$ in sterile tap water supplemented with $150 \mathrm{mM} \mathrm{NaCl}$ and given ad libitum to all mice for $6 \mathrm{~h}$ to 
1 initiate an oral infection. (A) Mice were observed for a period of 14 days post-infection for survival and

2 (B) alterations in body weight. For an oral dose of $10^{7} \mathrm{CFU} / \mathrm{ml}$, mutants in YopD show either no tendency

$3\left(\mathrm{YopD}_{\Delta 23-47}\right)$ or lower tendency $\left(\mathrm{YopD}_{\mathrm{I} 32 \mathrm{~K}}\right.$ and $\left.\mathrm{YopD}_{\mathrm{I} 32 \mathrm{P}}\right)$ to induce a terminal infection. This trend

4 corroborates body weight lost, which reflects general animal well-being. Strains: Parent (producing native 5 YopD), YPIII/pIB102; $\quad$ YopD $_{\Delta 23-47}, \quad$ YPIII/pIB605; $\quad$ YopD $_{\mathrm{I} 32 \mathrm{~K}}, \quad$ YPIII/pIB60501; $\quad$ YopD $_{\mathrm{I32P}}$, 6 YPIII/pIB60502. 


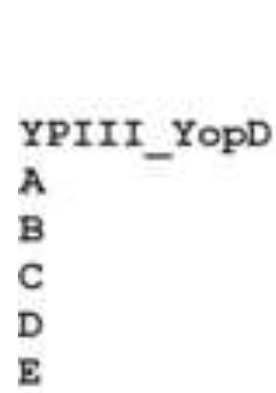

YPIII_YopD

A

$\mathrm{B}$

C

D

E

YPIII_YopD A

B

C

D

E

YPIII_YopD A

B

C

D

E

YPIII_YopD

YPIII_YopD
MTINIKTDSPIITTGSOLDAITTETVKOSGEIKKTEDTRHE

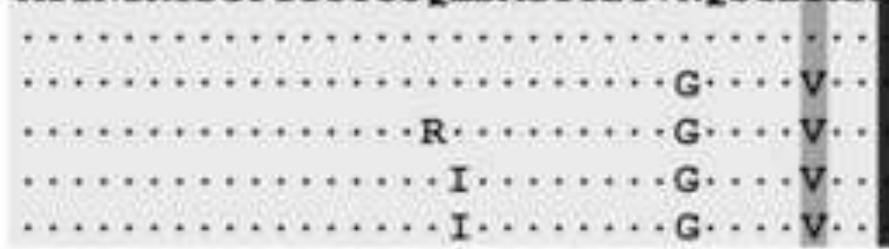

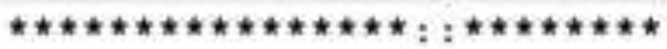

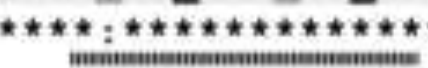



IKPSQGINVALLSKSQGDINGTLSILLLLLEI.ARKAREMGLOQRD IENKATTITAQKEQVA
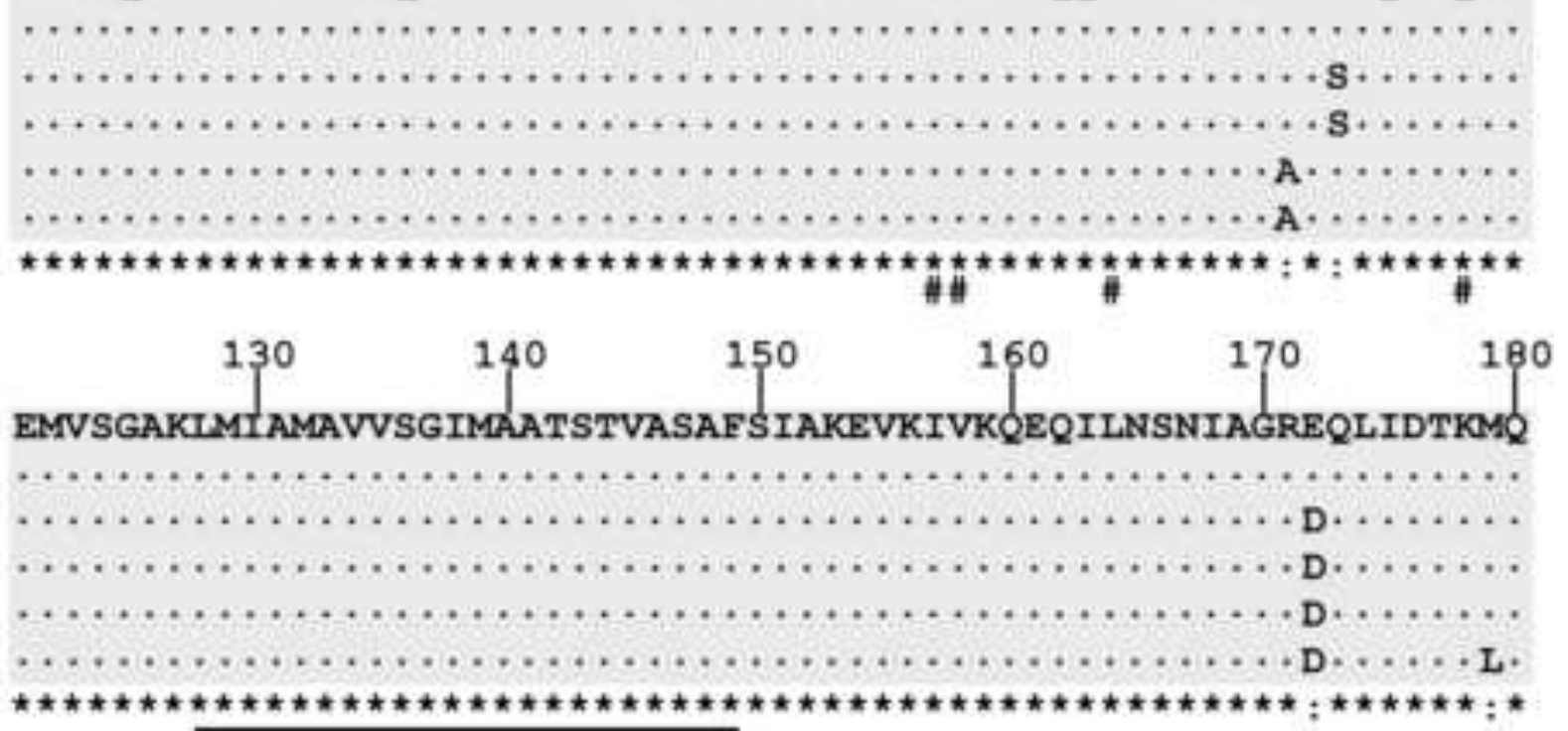

\#\#\#\#\#\#

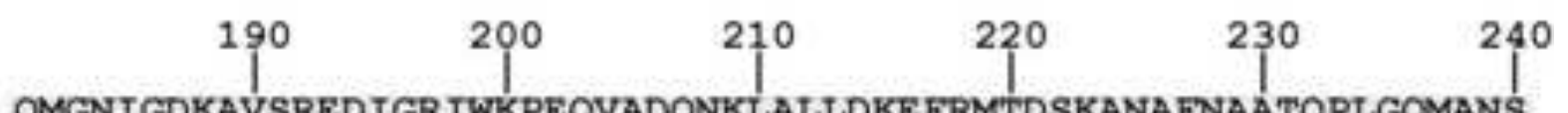

QMGNI GDKAVSREDIGR IWKPEQVADQNKLALLDKE FRMTDSKANAFNAATQPLGQMANS

$$
\begin{aligned}
& \text {. S } \\
& \text {-S.A } \\
& \text { - S A. } \\
& \text { - S.TS } \\
& \text {. S.TS }
\end{aligned}
$$

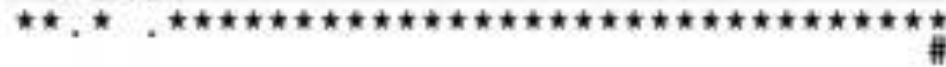

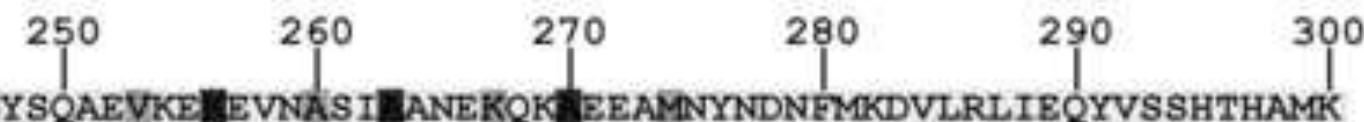

AIQVHQGYSQAEVKE EVNASI ANEKQKAEEAMNYNDNEMKDVLRLIEQYVSSHTHAMK

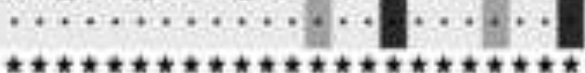

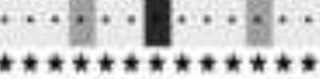

$\|$

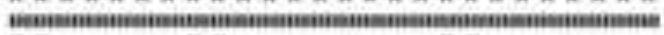

\#il

\#i

\#il

\section{AAFGVV}

$\star \star \star \star * \star *$

\# 


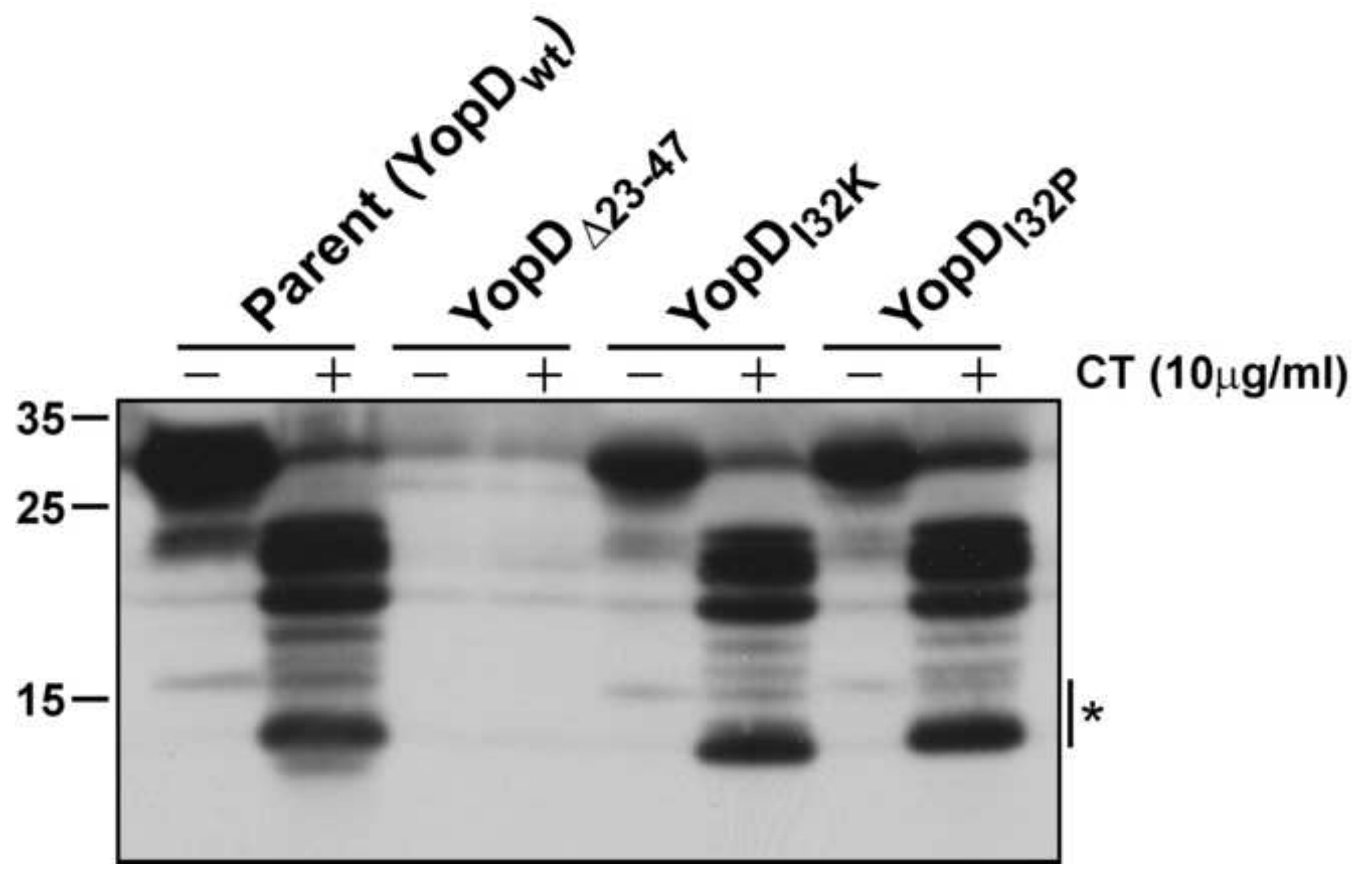



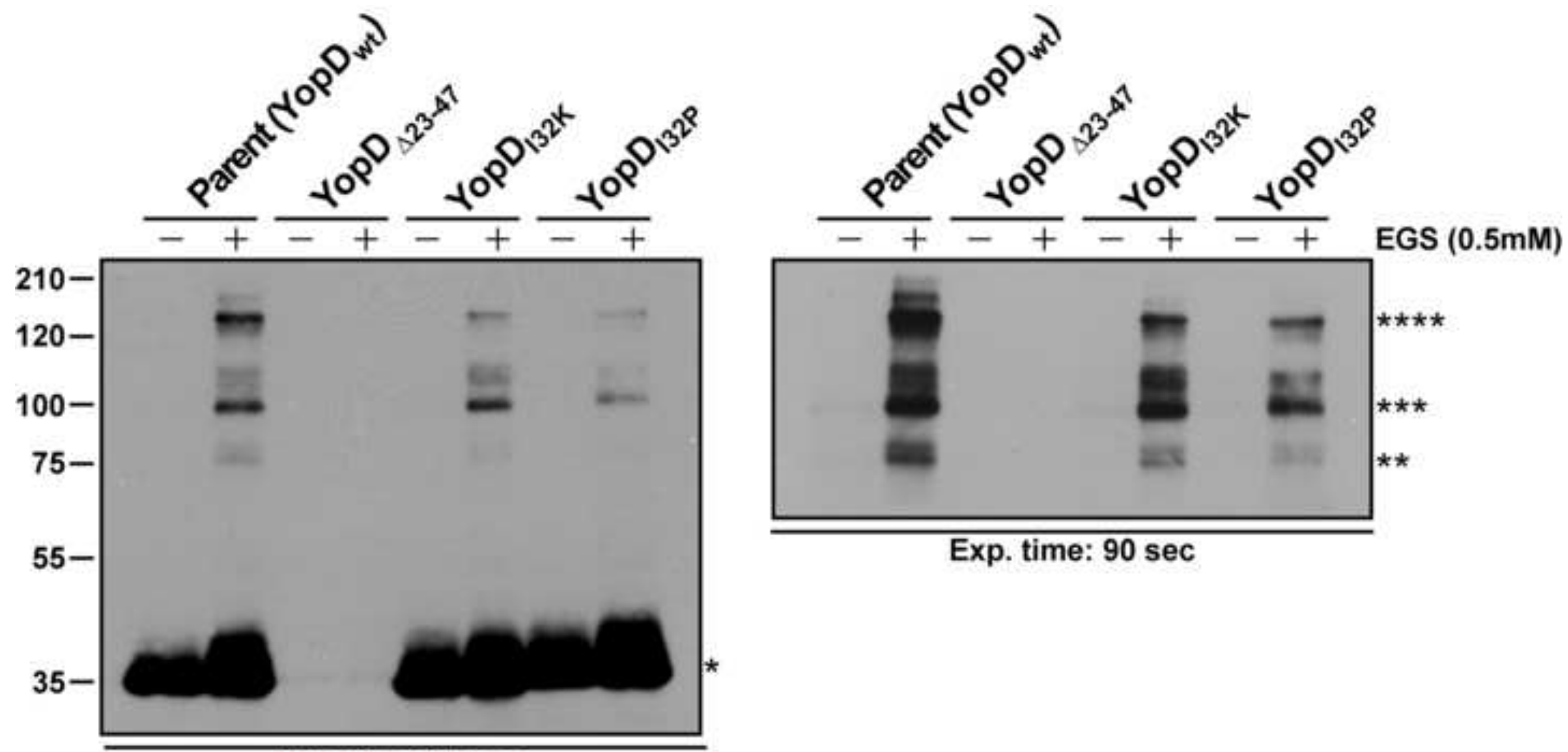

Exp. time: 15 sec 
Click here to download high resolution image

A

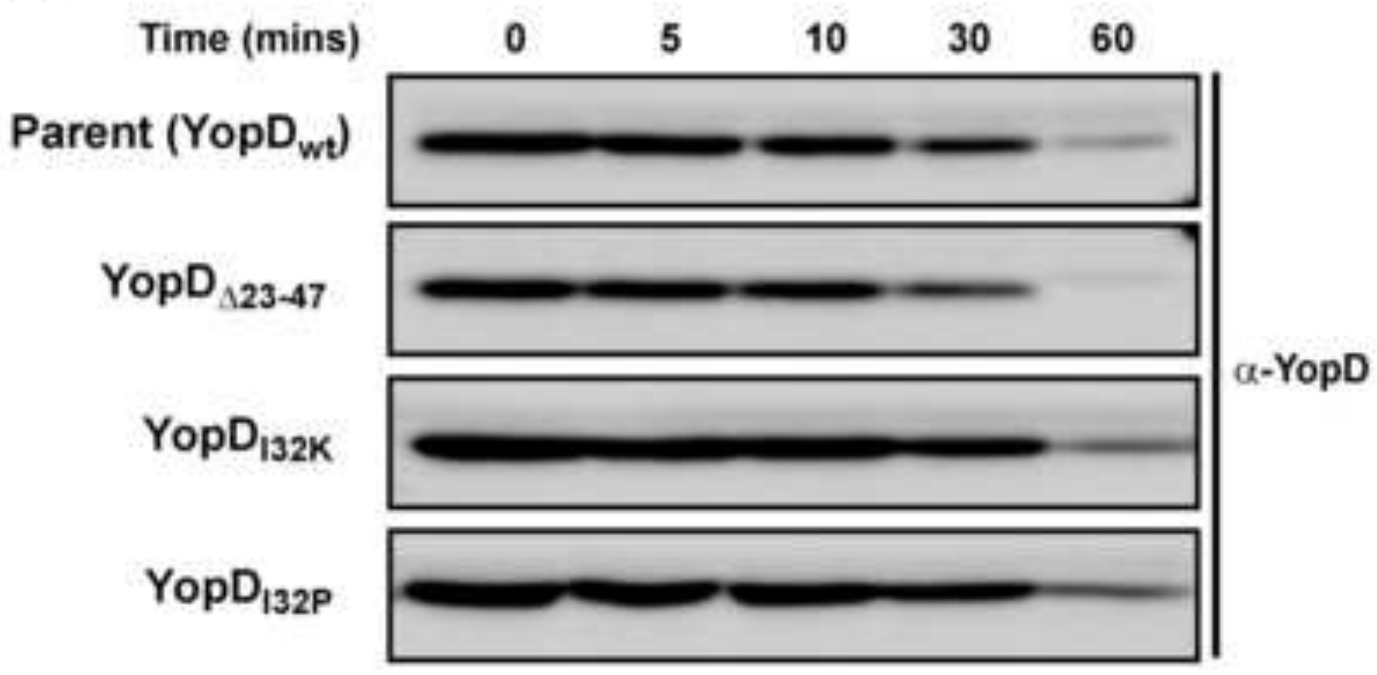

B
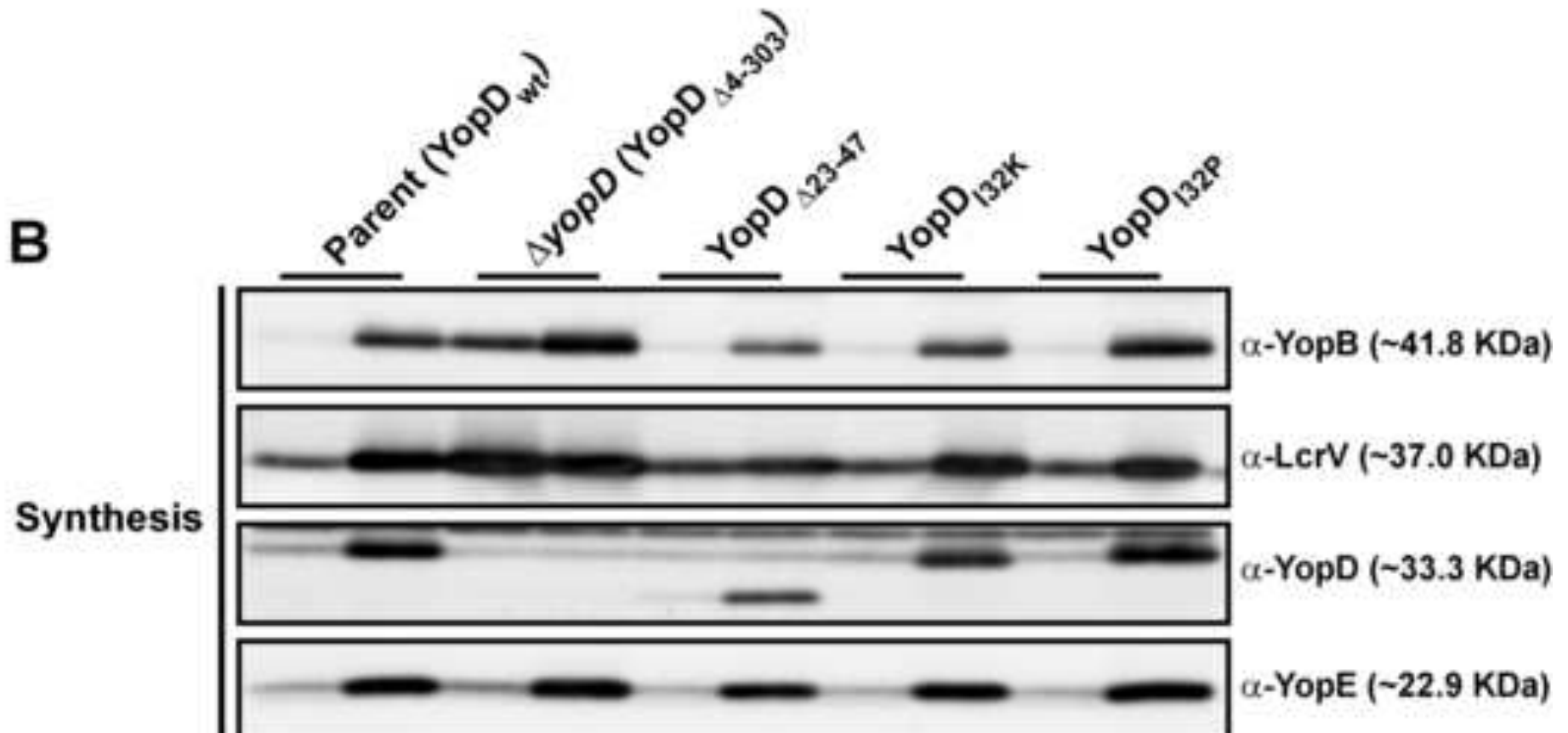

C

$$
+-+-+-+-+-\mathrm{Ca}^{2+}
$$

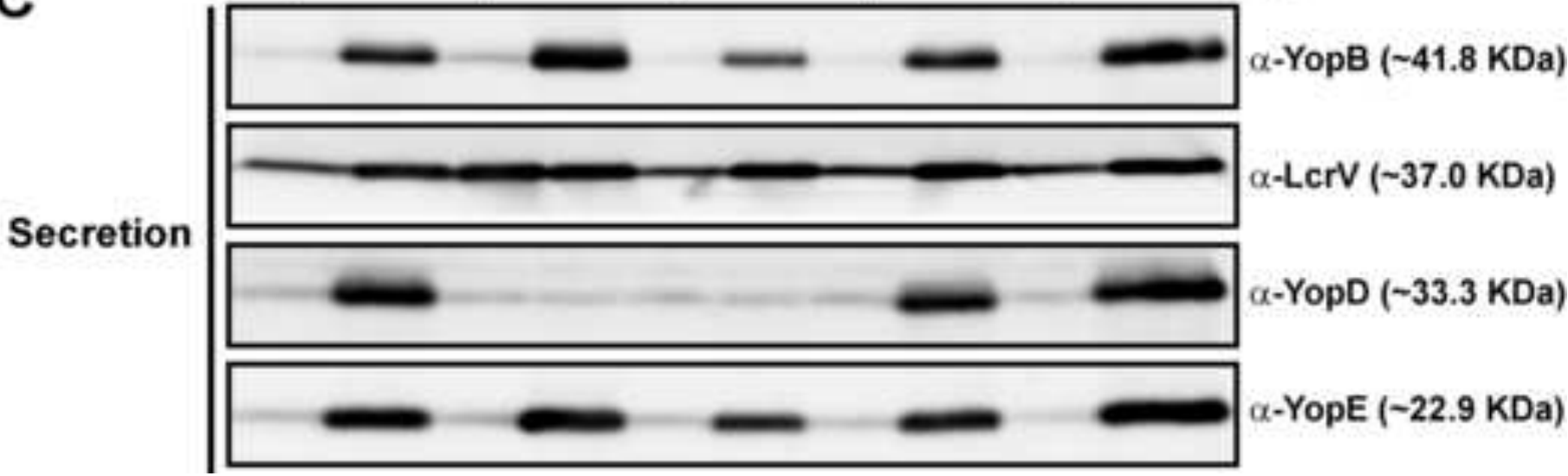



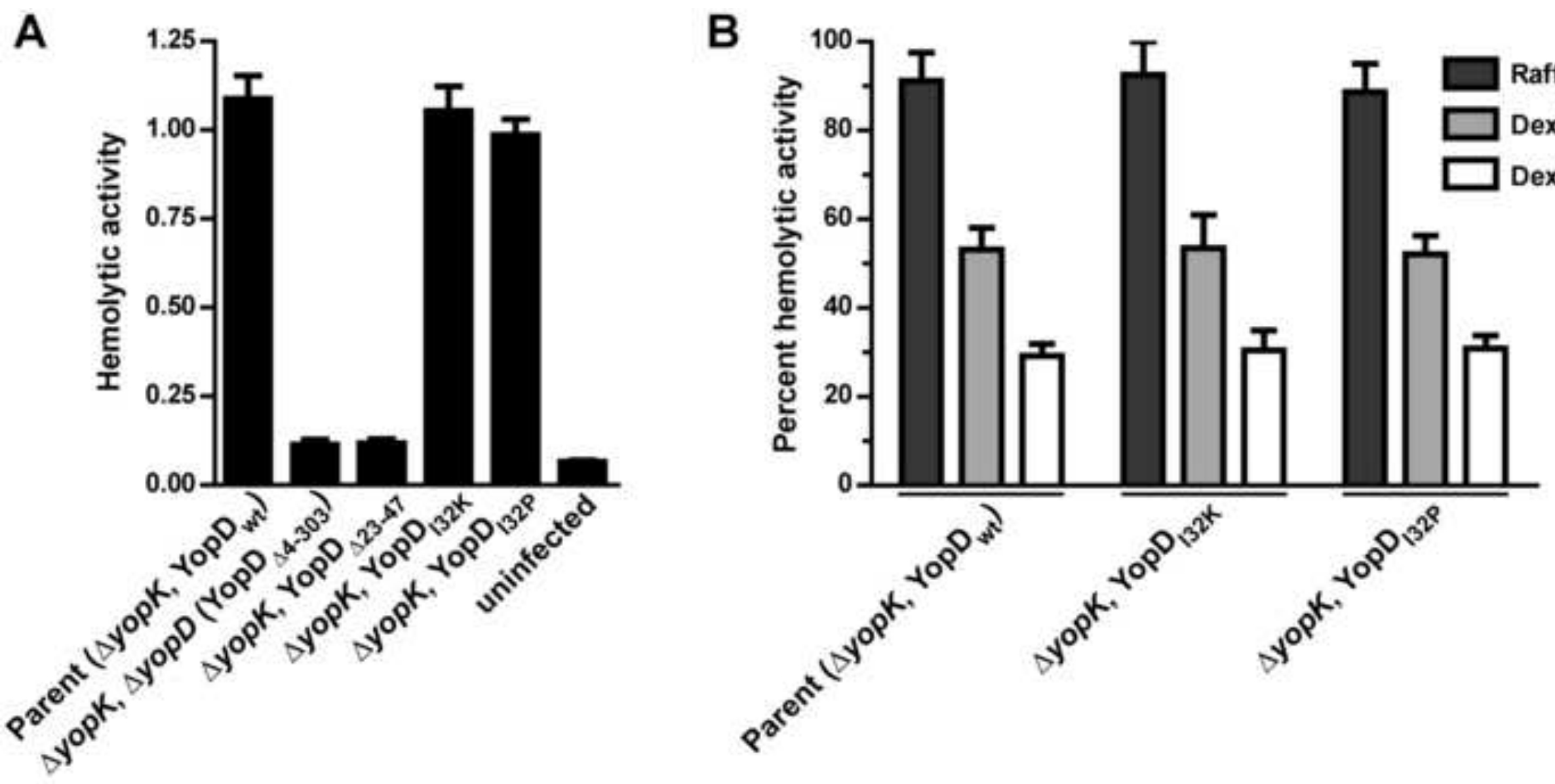


\section{Figure 6}

Click here to download high resolution image

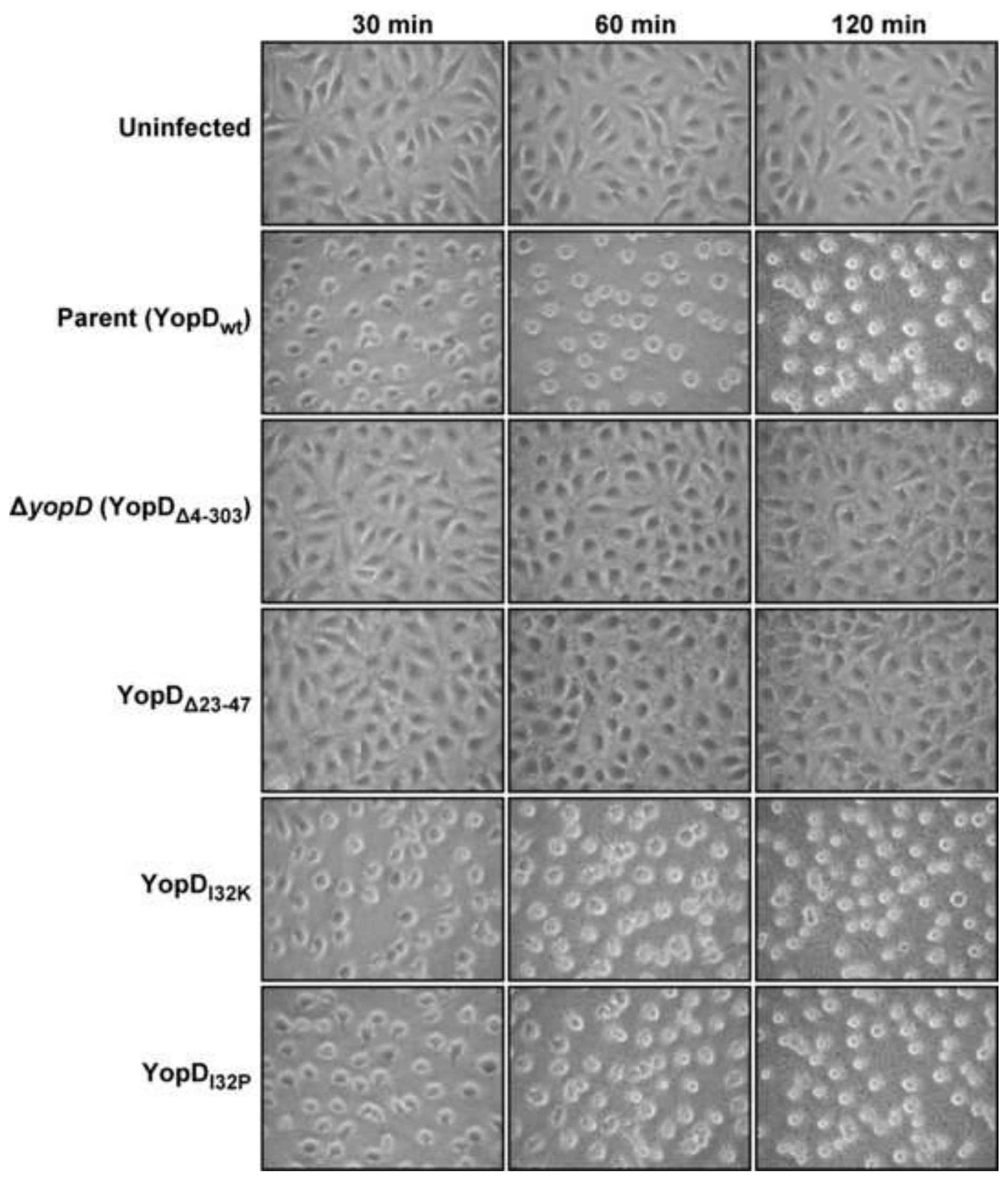


Click here to download high resolution image

A

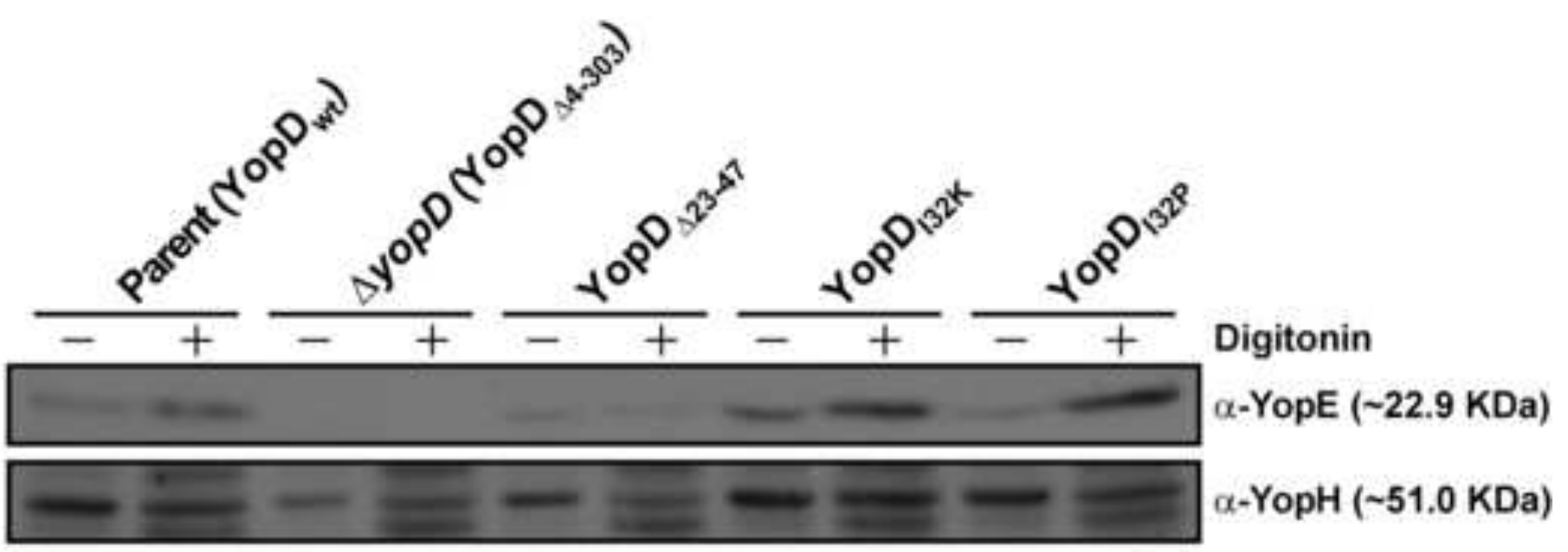

$\alpha$-Erk1 ( 42.0 KDa)

B

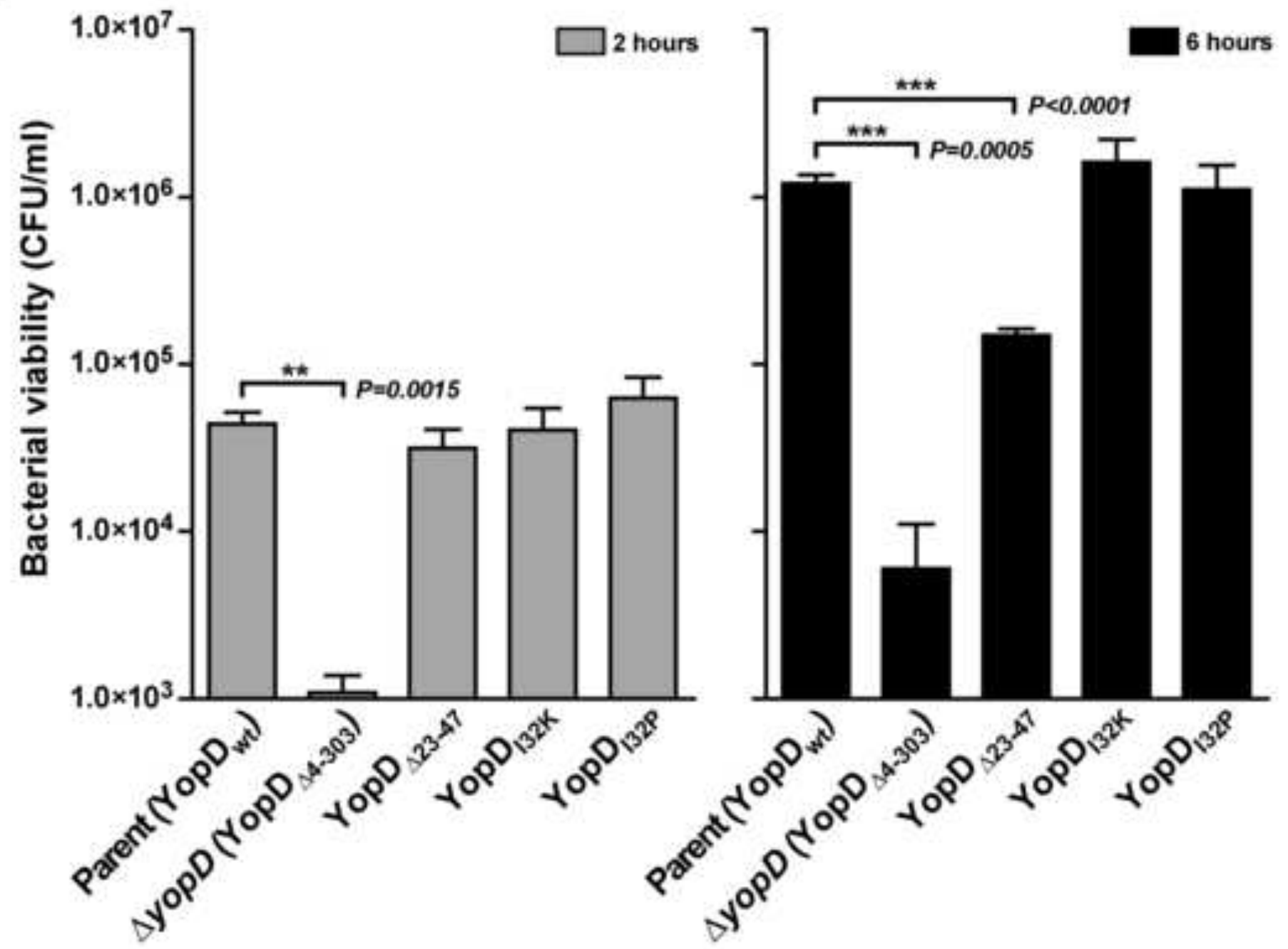




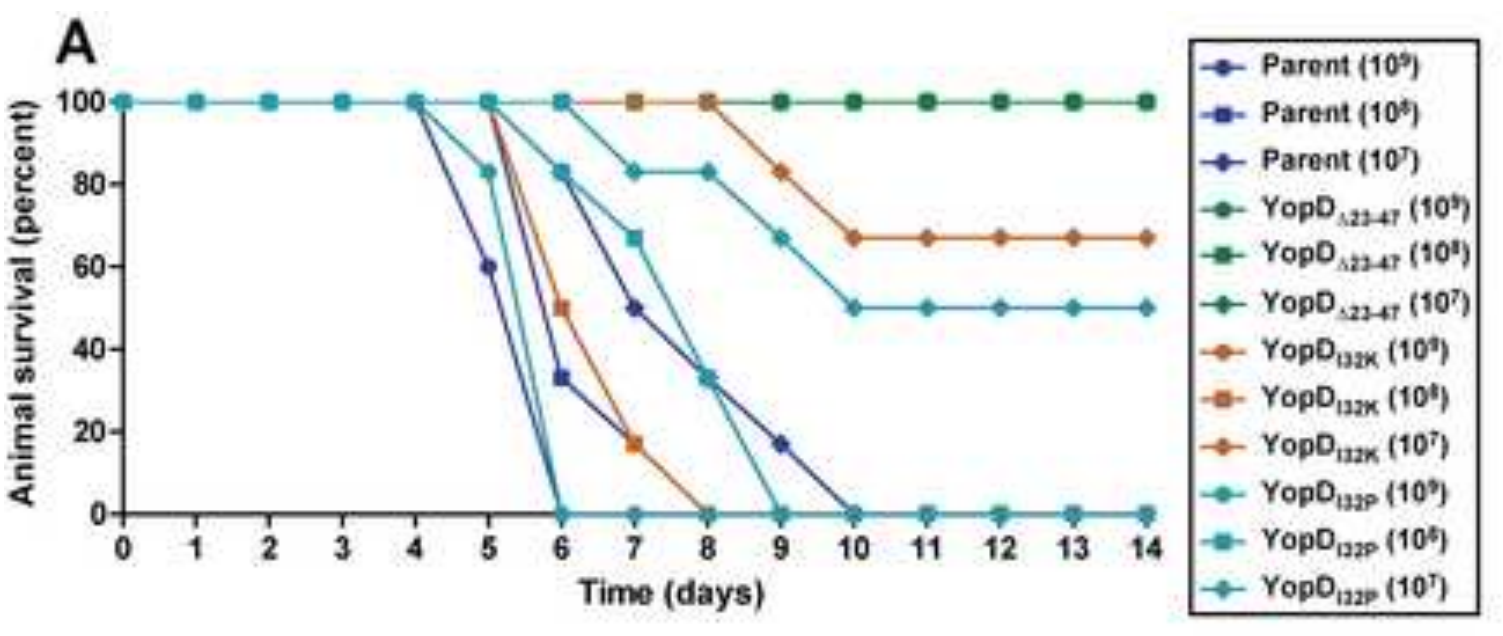

\section{B}

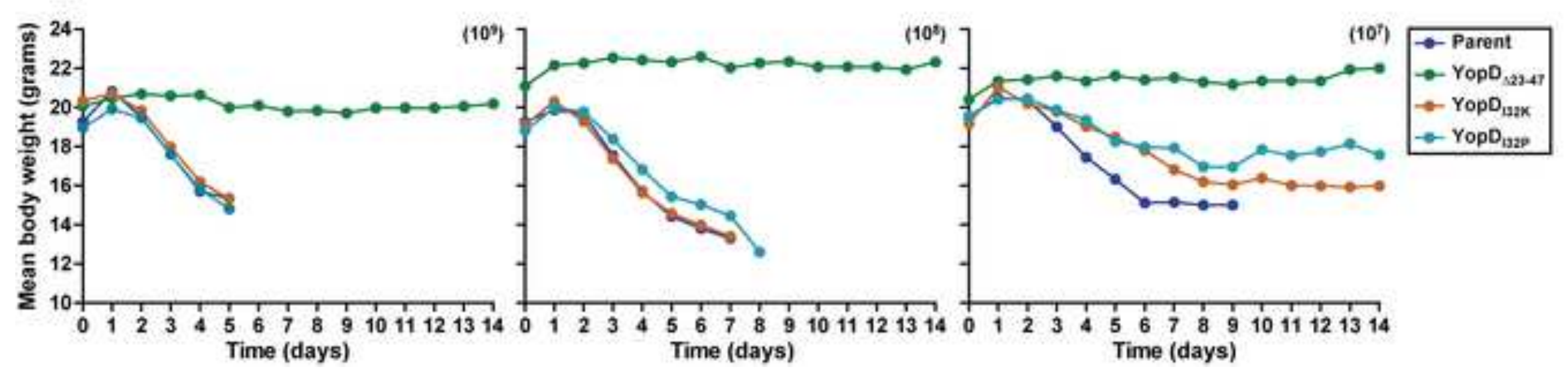


Costa et al., (2012) Supplemental Material 1 Coiled-coil domain required for full YopD function

\section{APPENDIX A:}

\section{Contents}

\section{Tables:}

Supplementary Table S1. Oligonucleotides used in this study

\section{Figures:}

Supplementary Figure S1. Coiled-coil prediction output profiles for selected sequences among the YopD family of type III secretion translocator proteins

\section{References:}




\section{Supplementary Table S2 Oligonucleotides used in this study}

\begin{tabular}{|c|c|}
\hline Purpose/vector & Oligonucleotide name and sequence \\
\hline \multicolumn{2}{|l|}{ Mutant construction } \\
\hline \multirow{4}{*}{ YopD $_{132 \mathrm{~K}}$} & pXhoA3 5'- ACGCTCGAGTACAACATAATAACGCTG - 3' \\
\hline & p(I32K)b 5'- GTCTTCTGTTTTTTTCTT CTCACCGCTTTGCTTGAC - 3' \\
\hline & p(I32K)с 5’- GAGAAGAAAAAAACAGAAGACA - 3' \\
\hline & pXbaD6 5'- ACGTTCTAGATAAAGTACCATTAAGATC - 3' \\
\hline \multirow{4}{*}{ YopD $_{132 \mathrm{P}}$} & pXhoA3 5'- ACGCTCGAGTACAACATAATAACGCTG - 3' \\
\hline & p(I32P)b 5' - GTCTTCTGTTTTTTTAGGCTCACCGCTTTGCTTGAC - 3' \\
\hline & p(I32P)с 5' - GAGCCTAAAAAAACAGAAGACA - 3' \\
\hline & pXbaD6 5' - ACGTTCTAGATAAAGTACCATTAAGATC - 3' \\
\hline
\end{tabular}

The nucleotide sequence in italics represents the incorporated restriction sites used for cloning of the PCR amplified DNA fragments. The base pair(s) underlined represent the amino acid substitution in each site-directed mutation. 
Costa et al., (2012) Supplemental Material 3 Coiled-coil domain required for full YopD function

A) Y. pseudotuberculosis YPIII (YopD; AAA72322)

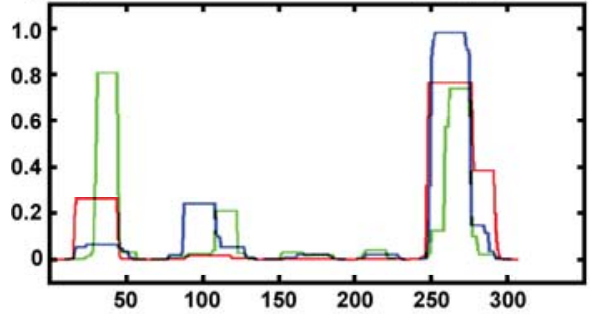

B) Y. pestis C092 (YopD; NP_395162)

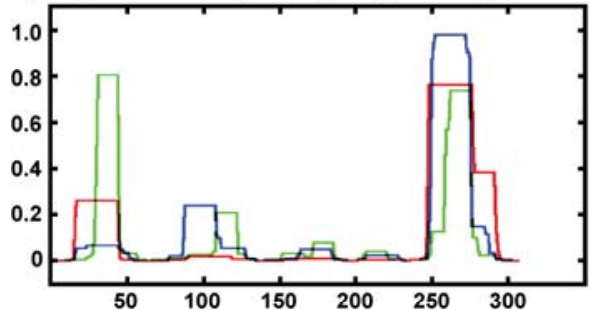

C) Y. enterocolitica W22703 (YopD; AAD16812)

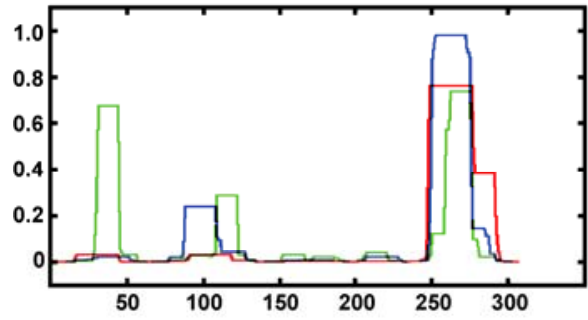

D) Y. enterocolitica A127/90 (YopD; NP_783662)

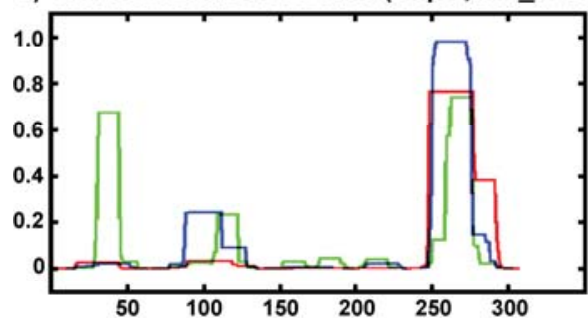

E) YPIII_YopD $132 P$

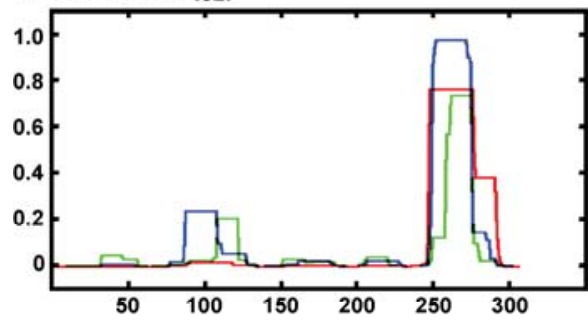

F) YPIII_YopD $D_{132 \mathrm{~K}}$

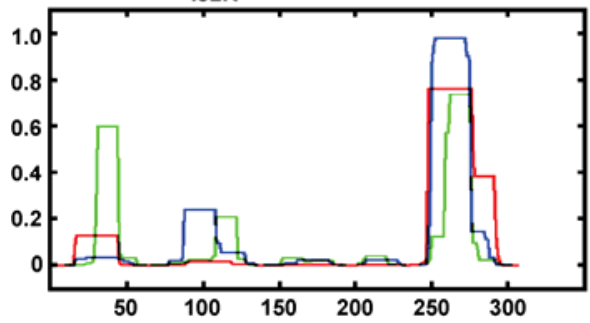

G) Aeromonas veronii HM21 (AopD; ABP51935)

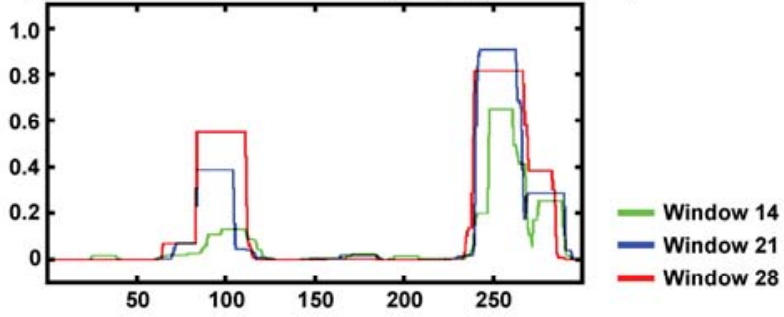

H) Aeromonas salmonicida A449 (AopD; YP_001144286)

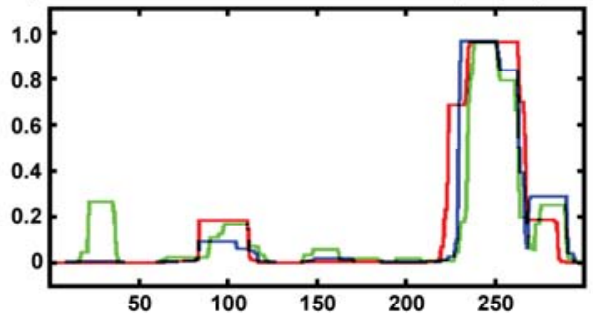

I) Photorhabdus luminescens W14 (LopD; AA018056)

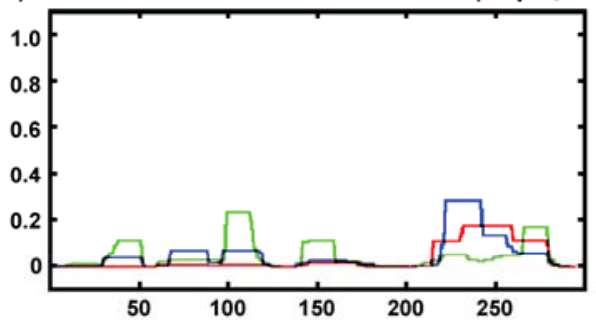

J) Pseudomonas aeruginosa HM21 (PopD; NP_250400)

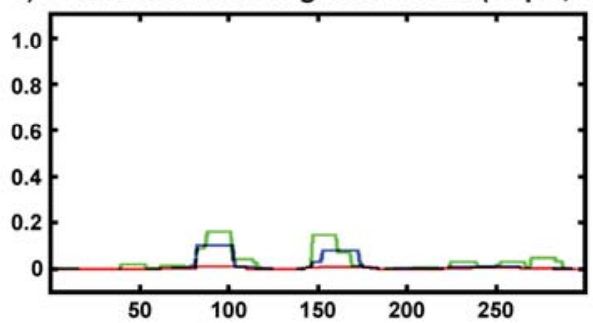

K) Vibrio paraaemolyticus RIMD 2210633 (VopD; NP_798035)

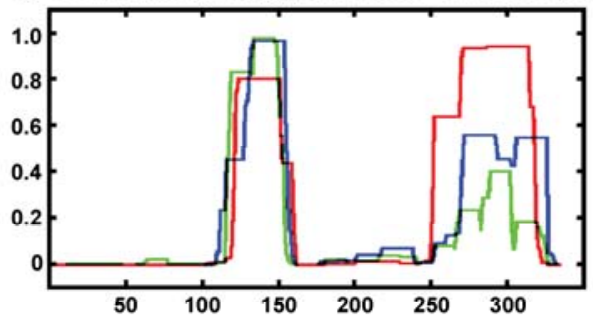

L) Photobacterium damselae CIP 102761 (VDA_000190; ZP_06157736)

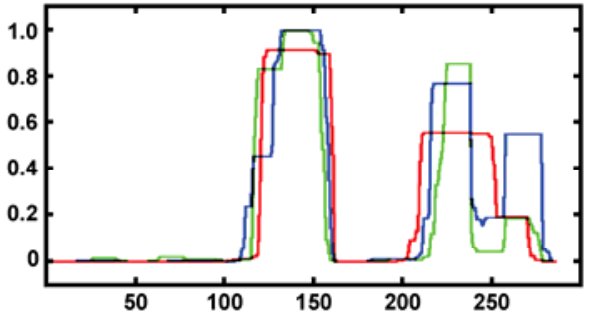




\section{Supplementary Figure S1. Coiled-coil prediction output profiles for selected sequences among the YopD family of type III secretion translocator proteins}

Coiled coil prediction profiles were generated using the unweighted method of Lupas and colleagues (Lupas et al., 1991) that is hosted by the Swiss Institute of Bioinformatics web server http://www.ch.embnet.org/software/COILS_form.html. Sequences are derived from the indicated bacterial species with the NCBI accession number displayed in parentheses. Evident is the heterogeneity among the coiled-coil prediction profiles. With a good degree of predictive certainty, all YopD sequences derived from pathogenic Yersinia sp. would be expected to possess a C-terminal coiled-coil (A to D). Additionally, a lower probability coiled coil is tentatively predicted for the extreme N-terminus. Given the unique positioning of this lowprobability coiled-coil, a goal of this study was to investigate if this region is important for YopD function. To do this, two substitution mutations in yopD from Y. pseudotuberculosis YPIII were generated. The resultant variants produced $\mathrm{YopD}_{\mathrm{I} 32 \mathrm{P}}$ and $\mathrm{YopD}_{\mathrm{I} 32 \mathrm{~K}}$. While the sequence of the later modestly reduced the coiled-coil prediction (F), the former mutant would not at all be expected to produce a coiled-coil in this region (E). Interestingly, predicted coiled-coils commonly locate nearer to the C-terminus of YopD homologues from other diverse bacteria (G, $\mathrm{H}, \mathrm{K}$ and $\mathrm{L}$ ), suggesting these regions might be particularly important for function of this translocator family. Exceptions do exist however, for neither YopD homologues from Photorhabdus luminescens (I) or Pseudomonas aeruginosa (J) appear likely to possess any coiled-coil structure. Functional comparisons between YopD family members with and without predicted coiled-coil regions could therefore be a useful approach to gain functional insight into this structure. Table 2 should be consulted for more information concerning the sequencing similarity within the YopD translocator family and predicted positioning of coiled-coil regions within individual homologues.

\section{References}

Lupas, A., Van Dyke, M., Stock, J., 1991. Predicting coiled coils from protein sequences. Science. 252, 1162-1164. 